\title{
Six-Step Gram Scale Synthesis of the HIV Integrase
}

\section{Inhibitor Dolutegravir Sodium}

Jule-Philipp Dietz, ${ }^{[a]}$ Tobias Lucas, ${ }^{[a]}$ Jonathan Groß,,${ }^{[a]}$ Sebastian Seitel, ${ }^{[a]}$ Jan Brauer, ${ }^{[a]}$ Dorota Ferenc, ${ }^{[a]}$ B. Frank Gupton, ${ }^{[b]}$ and Till Opatz, ${ }^{*[a]}$

[a] Department of Chemistry, Johannes Gutenberg-University, Duesbergweg 10-14, 55128

$$
\text { Mainz, Germany }
$$

[b] Department of Chemical and Life Sciences Engineering, Virginia Commonwealth University, Richmond, Virginia 23284, United States 


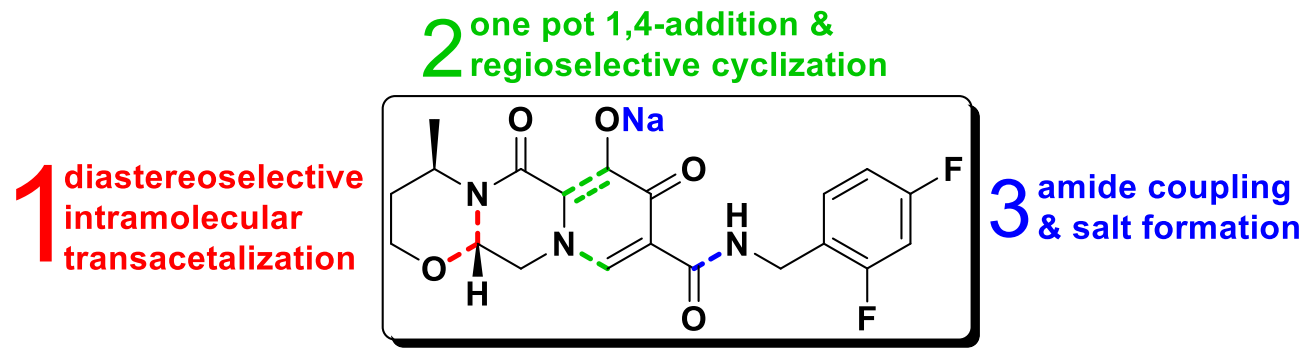

$51 \%$ IY over 6 steps

- no chromatography

- straightforward chemistry 
A short and practical synthesis for preparing the active pharmaceutical ingredient dolutegravir sodium was investigated. The convergent strategy developed herein starts from 3- $(R)$-amino-1butanol and builds up the $\mathrm{BC}$ ring system in $76 \%$ isolated yield over four steps. Ring A was constructed by a one-pot 1,4-addition to diethyl-(2E/Z)-2-(ethoxymethylidene)-3-oxobutandioate and subsequent $\mathrm{MgBr}_{2} \cdot \mathrm{OEt}_{2}$-mediated regioselective cyclization. Amide formation with 2,4difluorobenzylamine was either performed from the carboxylic acid or through aminolysis of the corresponding ester precursor. Final salt formation afforded dolutegravir sodium in $48-51 \%$ isolated yield (HPLC-purity: 99.7-99.9\%) over six linear steps.

KEYWORDS: dolutegravir sodium, active pharmaceutical ingredient, antivirals, integrase inhibitors, carbamoyl pyridones

\section{Introduction}

Infection with the human immunodeficiency virus (HIV) has become controllable in recent years due to enormous progress in development of highly active drugs which are given for antiretroviral therapy (ART). ${ }^{1}$ ART requires the administration of at least three different antiviral drugs to suppress the development of resistances. ${ }^{2}$ Differentiated by the target enzyme, there are several classes of HIV-inhibiting drugs. The class of integrase strand transfer inhibitors (INSTIs) interferes with the HIV integrase enzyme and prevents it from inserting viral DNA into the human genome. INSTIs have been introduced in 2007 with the launch of raltegravir (1), followed by elvitegravir (2, 2012), dolutegravir $(\mathbf{3}, 2013)$, bictegravir $(\mathbf{4}, 2018)$ and cabotegravir $(\mathbf{5}, 2021)^{3}$ (Scheme 1). ${ }^{4}$ 


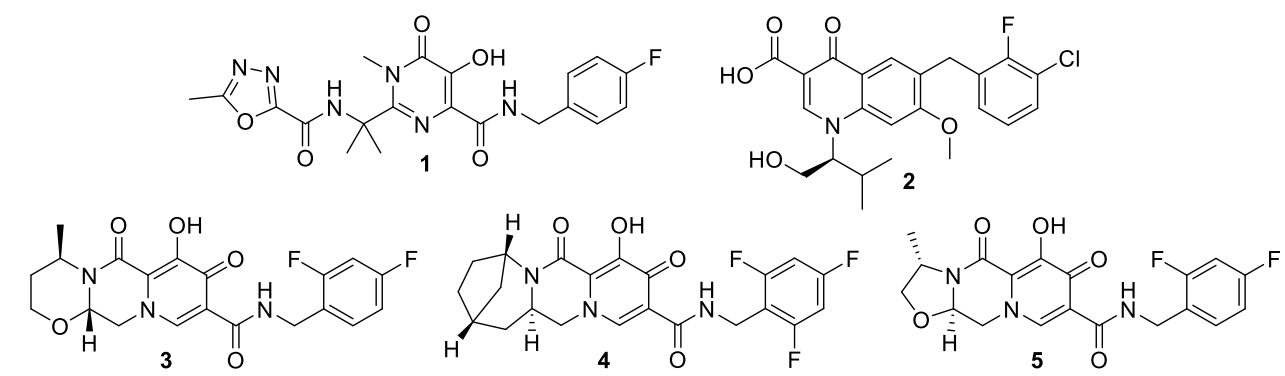

Scheme 1: Structures of raltegravir (1), elvitegravir (2), dolutegravir (3), bictegravir (4) and cabotegravir (5).

The last three compounds exhibit a high similarity in their molecular structures, assigning them to the group of carbamoyl pyridine INSTIs. Dolutegravir (3), usually administered orally as its sodium salt, was recently recommended by the World Health Organization for first-line treatment of HIV initiating ART. ${ }^{5}$ As a consequence, the demand of this important medication could further rise.

Synthetic approaches to $\mathbf{3}$ have been carefully reviewed. ${ }^{4,6}$ All industrially conducted syntheses follow a similar strategy, which is represented here by the hitherto most efficient approach from Micro Labs (2016) ${ }^{7}$ (Scheme 2). The highly functionalized pyridone 7 (ring A) is constructed first, which then undergoes cyclization with 3-(R)-amino-1-butanol 13 to construct ring $\mathrm{B}$ and $\mathrm{C}$. Deprotection of the usually protected enol and treatment with sodium hydroxide furnish dolutegravir sodium (15). The seven-step synthesis by Micro Labs afforded $\mathbf{1 5}$ in 29\% overall yield. This retained synthesis concept could be attributed to the late-stage introduction of the expensive amino alcohol 13. 

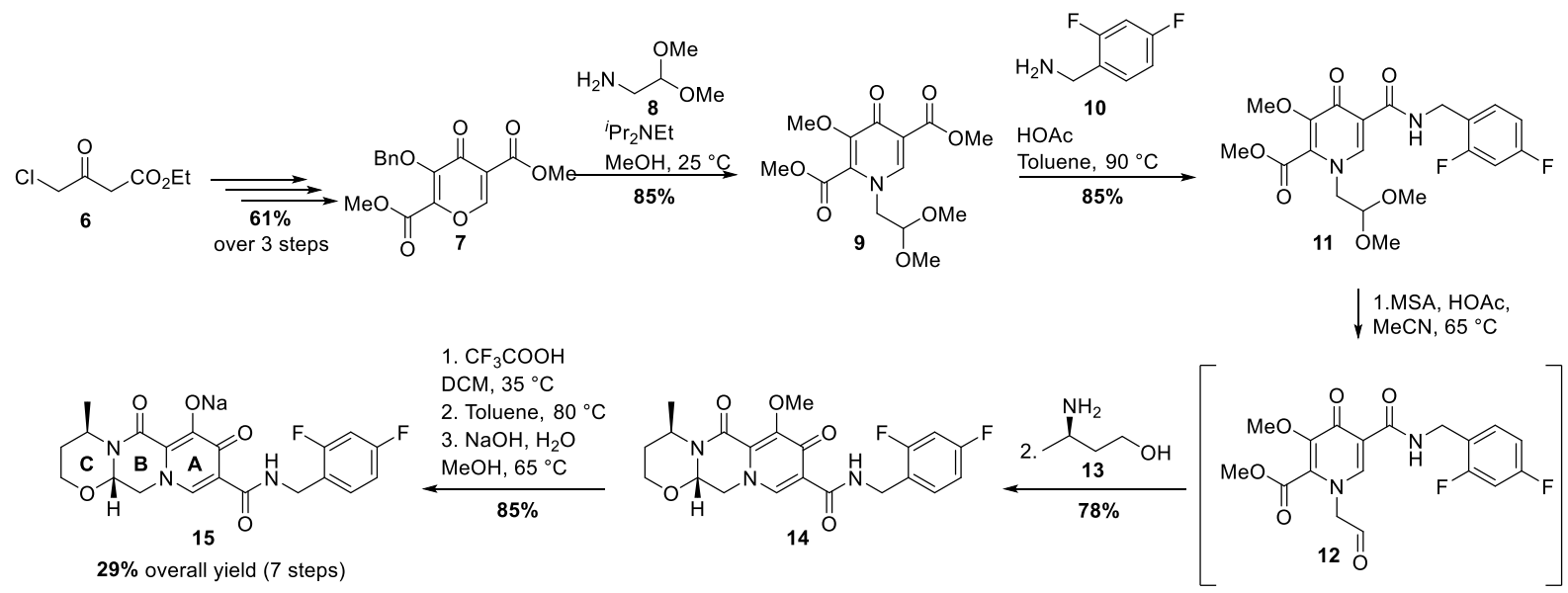

Scheme 2: Synthesis of dolutegravir by Micro Labs (2016).

Since the discovery of dolutegravir and the emerging demand of 3-(R)-amino-1-butanol (13), more efficient syntheses of this crucial building block have been developed with the consequence of a decreasing market price. ${ }^{8}$ Thus, an earlier introduction of $\mathbf{1 3}$ could add additional value by bringing more diversification to the synthetic portfolio of dolutegravir. Extending the scope of industrially applicable synthetic routes should encourage generic manufacturing to ensure global supply of this important drug.

Herein, a new synthetic route should be investigated by taking $\mathbf{1 3}$ as starting material (Scheme 3). By using commodity chemicals, the ring-system BC (16) should be constructed first. Next, 16 should be reacted with readily accessible diethyl-(2E/Z)-2-(ethoxymethyliden)-3-oxobutandioate (17) to install ring A. Amide coupling with 1,4-difluorobenzylamine and salt formation follow in the last step. All in all, an industrially feasible synthesis route was intended to be developed . 


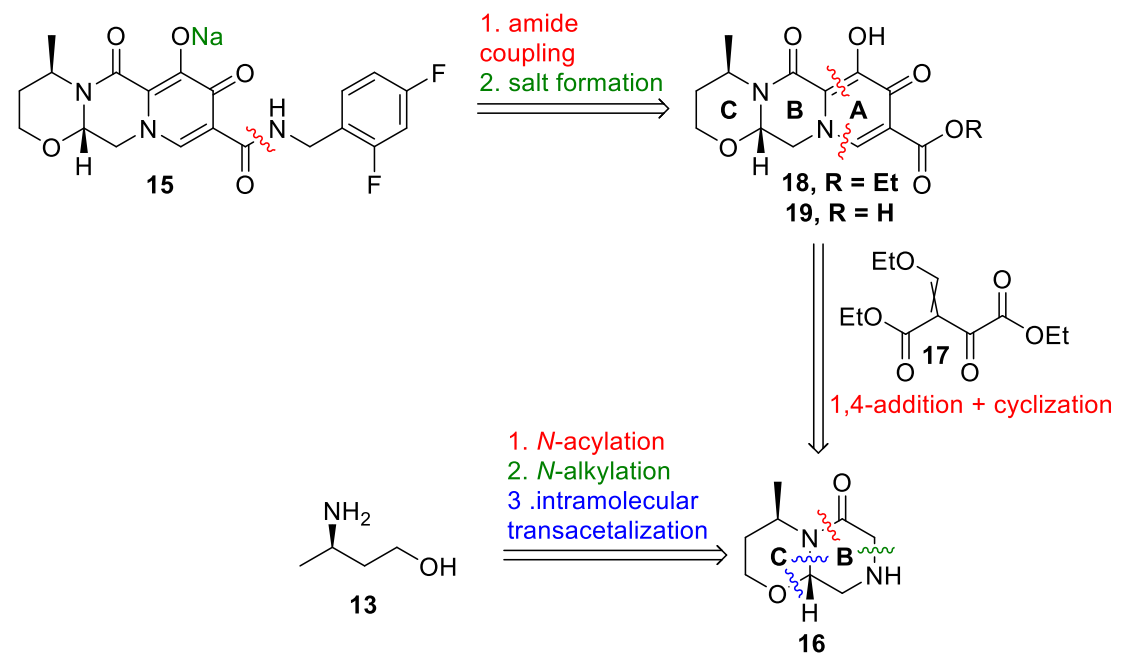

Scheme 3. Retrosynthetic strategy towards dolutegravir (15).

\section{Results and discussion}

\section{Synthesis of ring system BC}

The synthesis of amine $\mathbf{1 6}$ has already been described twice in patent literature. Lerner et al. reported a five step synthesis starting form ethyl bromoactetate (19) furnishing amine 16 in $24 \%$ overall yield. ${ }^{9}$ The crucial cyclization with amino alcohol 13 gave only 55\% yield under microwave conditions and chromatographic steps were required. During our synthetic work, a patent from Virginia Commonwealth University was disclosed, which describes a similar but more efficient approach towards $\mathbf{1 6} .^{10}$ The methyl ester of intermediate $\mathbf{2 4}$ was prepared in three steps from methyl glycinate ( in $66 \%$ yield. The cyclization step was performed in a toluene/methanol/acetic acid mixture and achieved 71\% yield after column chromatography. Removing the Cbz-group at higher hydrogen pressure gave slightly better results and amine 16 was finally obtained in $44 \%$ over five steps. The synthesis was even performed on a multigram scale but required two chromatographic steps. 


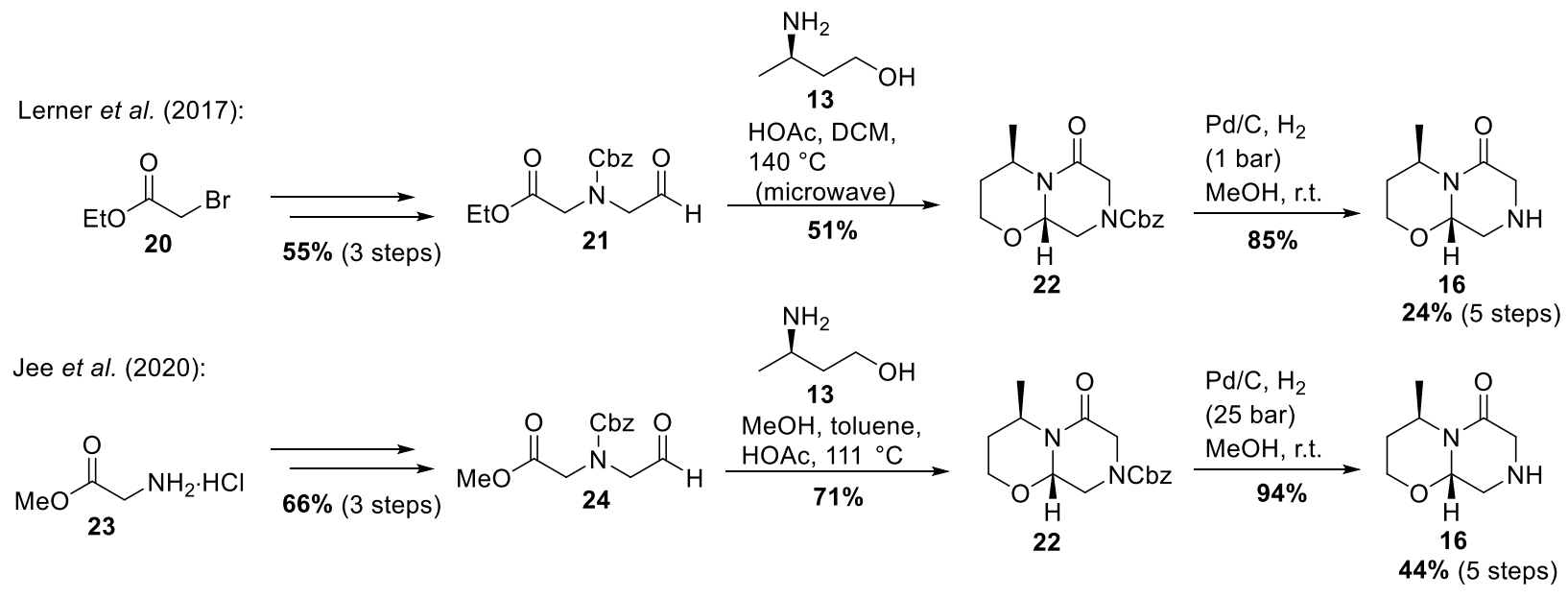

Scheme 4: Known syntheses of amine $\mathbf{1 6 .}$

A potentially shorter approach could be achieved by first $N$-acylating $\mathbf{1 3}$ with chloroacetyl chloride (25) (Scheme 5). Subsequent alkylation with aminoacetaldehyde dimethyl acetal (8) would furnish the acyclic precursor 27. Acid-catalyzed intramolecular transacetalization would in turn afford the desired amine $\mathbf{1 6 .}$

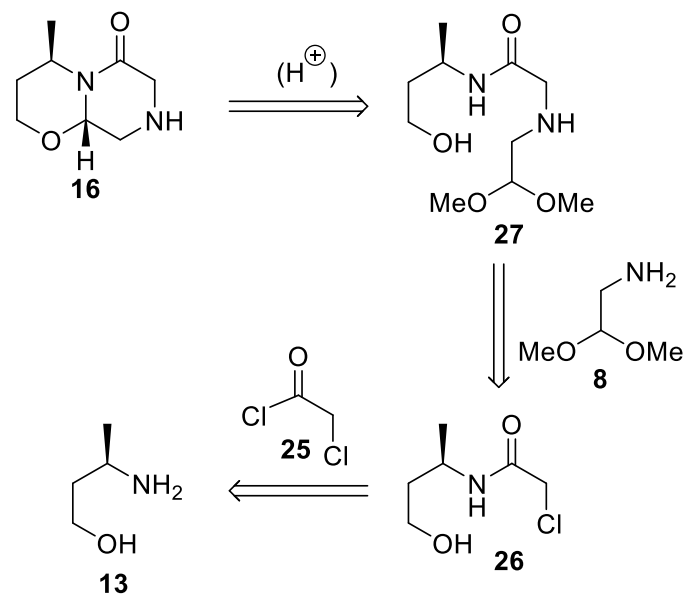

Scheme 5: Retrosynthetic proposal towards amine $\mathbf{1 6 .}$

When the acylation of $\mathbf{1 3}$ was performed under standard conditions $\left(\mathrm{NEt}_{3}, \mathrm{DCM}, 0{ }^{\circ} \mathrm{C}\right)$, a mixture of desired $\mathbf{2 6}$ and $\mathrm{N}, \mathrm{O}$-bis-acylated compound $\mathbf{2 8}$ was obtained (Scheme 6). Nevertheless, $\mathbf{2 8}$ could be easily saponified to $\mathbf{2 6}$ by just adding aqueous base to the crude reaction mixture. 
After extractive workup, only a $40 \%$ isolated yield of $\mathbf{2 6}$ was obtained. It turned out that large amounts of $\mathbf{2 6}$ had remained in the aqueous phase. When the water was removed in vacuo and the salty residue was suspended in ethyl acetate, a further $40 \%$ of $\mathbf{2 6}$ could be isolated.

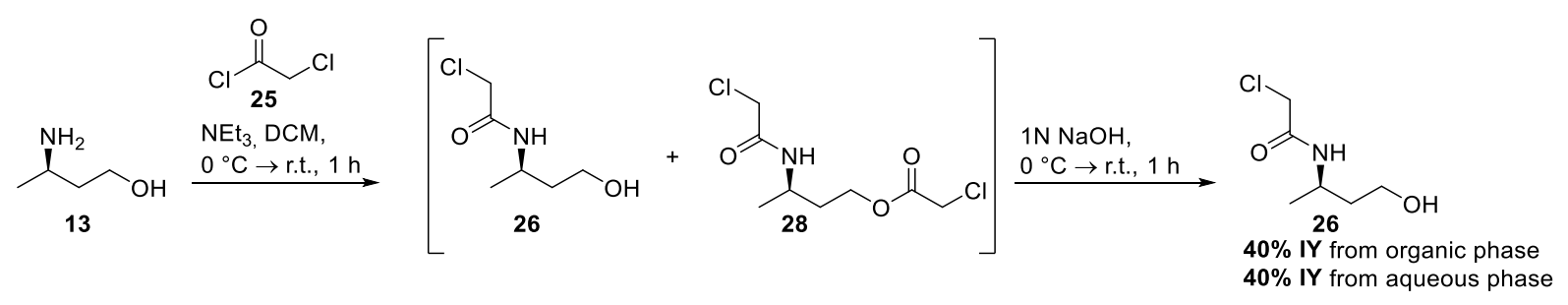

Scheme 6: $N$-Acylation of 3-(R)-amino-1-butanol (13).

Due to the high polarity of $\mathbf{2 6}$, the whole process was adjusted by using continuous extraction. After complete saponification of $\mathbf{2 8}$, which was followed by GC-MS, the organic phase was separated and additionally extracted with water. The combined aqueous phases were neutralized with acid, transferred into a Kutscher-Steudel apparatus and continuously extracted for $72 \mathrm{~h}$ with ethyl acetate. This procedure enabled the isolation of $\mathbf{2 6}$ in $91 \%$ isolated yield. It should be noted that $\mathbf{2 6}$ showed a high purity according to ${ }^{1} \mathrm{H}-\mathrm{NMR}$ and no further purification step was required.

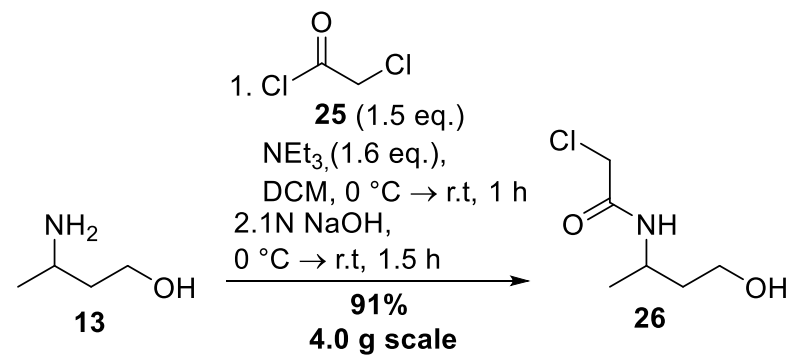

Scheme 7: $N$-Acylation of $\mathbf{1 3}$ with chloroacetyl chloride.

In the next step, $\mathbf{2 6}$ should be used for alkylating aminoacetaldehyde dimethyl acetal (8) to form the secondary amine $\mathbf{2 7}$. The reaction was performed either by heating in toluene or by stirring at r.t. in DCM in the presence of sodium iodide (Scheme 8). After aqueous workup, only $33-45 \%$ of 
crude 27 could be isolated. As already reported for the previous reaction, a significant quantity of 27 remained the aqueous phase which could not be separated from excess amine 8. Through LCMS, one main impurity could be identified as the tertiary amine 29. To circumvent its formation and to solve the water solubility issue, another strategy was chosen.

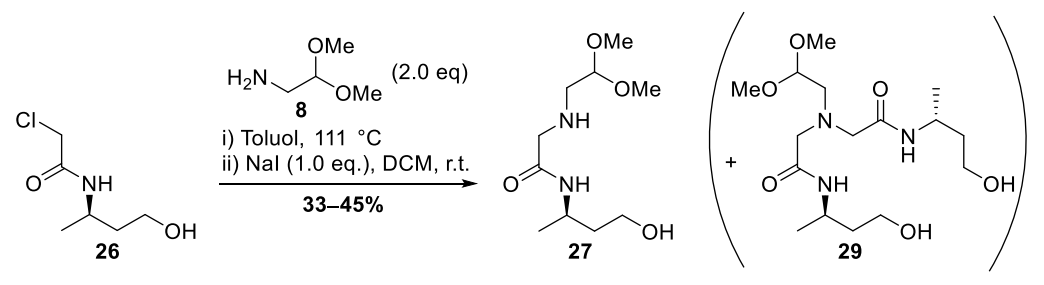

Scheme 8: $N$-Alkylation of aminoacetaldehyde dimethyl acetal (8) with 26.

By converting primary amine $\mathbf{8}$ into a secondary and more lipophilic amine first, subsequent alkylation would lead to a tertiary and better extractable amine. Benzylation of $\mathbf{8}$ proved to be a good option as it can be easily reverted by hydrogenation. $N$-benzyl-2,2-dimethoxyethylamine (30) was prepared in two different ways (Scheme 9). When heating chloroacetaldehyde-dimethylacetal (31) with an excess of benzylamine (32) in toluene, $77 \%$ of $\mathbf{3 0}$ was isolated after distillation. According to a procedure from Luu et al., $\mathbf{3 0}$ could also prepared through reductive amination from stochiometric amounts of benzaldehyde (33) and aminoacetaldehyde dimethyl acetal (8). ${ }^{11}$ The latter method furnished $\mathbf{3 0}$ in $97 \%$ isolated yield.
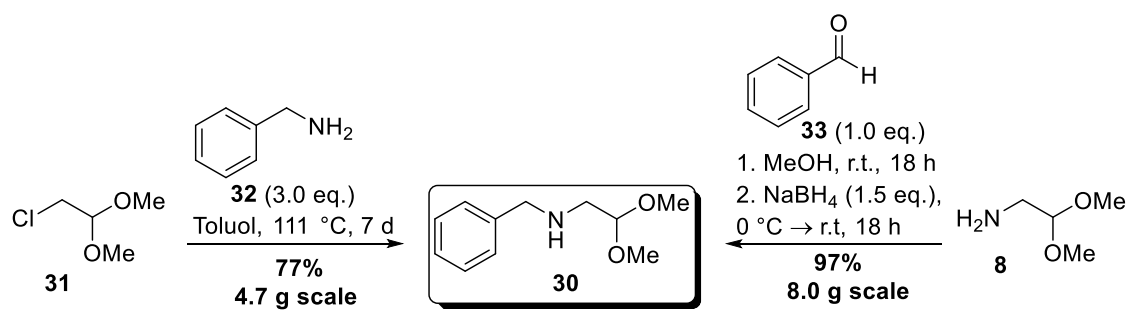

Scheme 9: Synthesis of $N$-benzyl-2,2-dimethoxyethylamine (30) by $N$-alkylation or reductive amination. 
Using secondary amine $\mathbf{3 0}$ instead of primary amine $\mathbf{8}$ for the alkylation gave much better results (Scheme 10). The reaction was performed in acetonitrile $(\mathrm{MeCN})$ in the presence of potassium iodide (KI) and potassium carbonate $\left(\mathrm{K}_{2} \mathrm{CO}_{3}\right)$. Complete conversion of 26 was observed after $24 \mathrm{~h}$ at r.t. or after three hours when heating to reflux. For workup, MeCN was removed and an extraction from water/ethyl acetate furnished $\mathbf{3 4}$ as a slight brownish oil. Again, the reaction proceeded very cleanly and no further purification of the product was necessary.

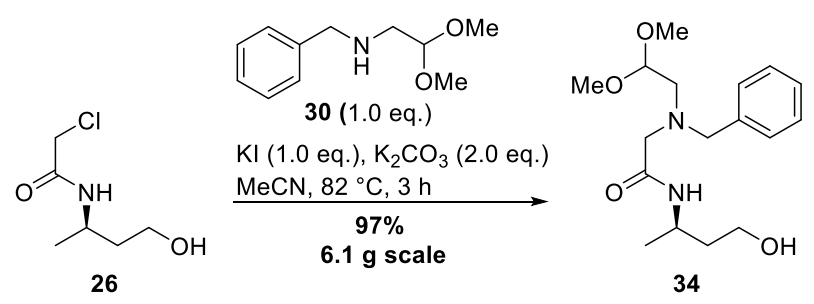

Scheme 10: Synthesis of tertiary amine $\mathbf{3 4}$ from $\mathbf{2 6}$ and $\mathbf{3 0}$ by heating in $\mathrm{MeCN}$ in the presence of $\mathrm{KI}$ and $\mathrm{K}_{2} \mathrm{CO}_{3}$.

34 cyclized cleanly in aqueous hydrochloric acid to the desired diastereomer of oxazinone $\mathbf{3 5}$ (Table 1). At least $6 \mathrm{~N} \mathrm{HCl}$ was necessary to achieve complete conversion after $48 \mathrm{~h}$ at r.t.. When the reaction was performed on a $11.5 \mathrm{~g}$ scale, crude $\mathbf{3 5}$ was isolated in $92 \%$ yield as a brown oil and only contained slight impurities. For the workup, the reaction mixture was neutralized with sodium hydroxide and extracted with ethyl acetate.. The enantiomeric excess of $\mathbf{3 5}$ was determined by chiral HPLC. Rac. 35 was prepared as reference material in the same way starting from rac-3(R)-amino-1-butanol (rac-35).

Table 1: Intramolecular transacetalization of $\mathbf{3 4}$.

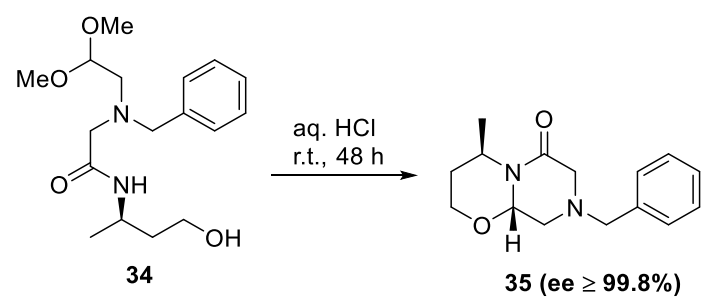




\begin{tabular}{cccc}
\hline entry & solvent & conversion [\%] & IY [\%] \\
\hline $\mathbf{1}$ & $1 \mathrm{~N} \mathrm{HCl}$ & 4 & - \\
\hline $\mathbf{2}$ & $3 \mathrm{~N} \mathrm{HCl}$ & 34 & - \\
\hline $\mathbf{3}$ & $6 \mathrm{~N} \mathrm{HCl}$ & 100 & 92
\end{tabular}

${ }^{a}$ determined by LC-MS at $254 \mathrm{~nm} .{ }^{b} 11.5 \mathrm{~g}$ scale.

The benzyl group was subsequently removed by hydrogenation (Scheme 11). The long reaction time could be probably shortened by applying a higher hydrogen pressure and/or a higher temperature. Nevertheless, crude amine 16 was obtained in 96\% yield (78\% IY over four steps) as a brown-orange oil which solidified after a while to beige and well-weighable solid. According to LC-MS and ${ }^{1} \mathrm{H}-\mathrm{NMR}$, minor impurities could be detected in the crude material (see corresponding spectra in the supporting information). Crude 16 was used for the next step and no further purification efforts were investigated.
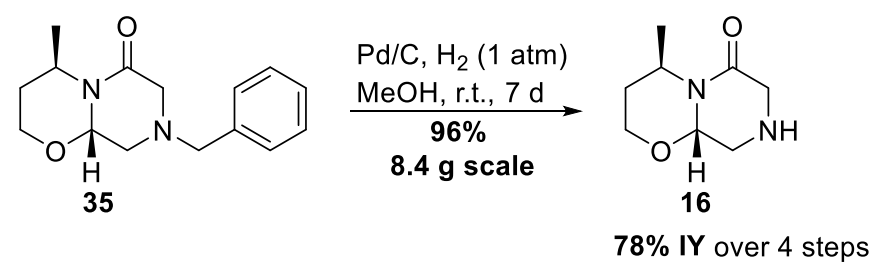

Scheme 11: Debenzylation of 35 by hydrogenation

\section{Construction of ring $\mathrm{A}$}

Jee et al. also reported a synthesis route to dolutegravir starting from ring system BC (16) (Scheme 12). ${ }^{10}$ Intermediate 39, which contains the crucial tricarbonyl moiety, was installed in two steps in $89 \%$ yield. Ring A was constructed by regioselective cyclization using magnesium bromide ethyl etherate $\left(\mathrm{MgBr}_{2} \cdot \mathrm{OEt}_{2}\right)$ and triethylamine $(65 \%$ yield of 40$)$. Subsequent amide coupling afforded desired dolutegravir 3 in 67\% yield. The route depicts the first one reported 
where ring system $\mathrm{AB}$ was constructed first. The overall yield was only $17 \%$ and five chromatographic steps were required.
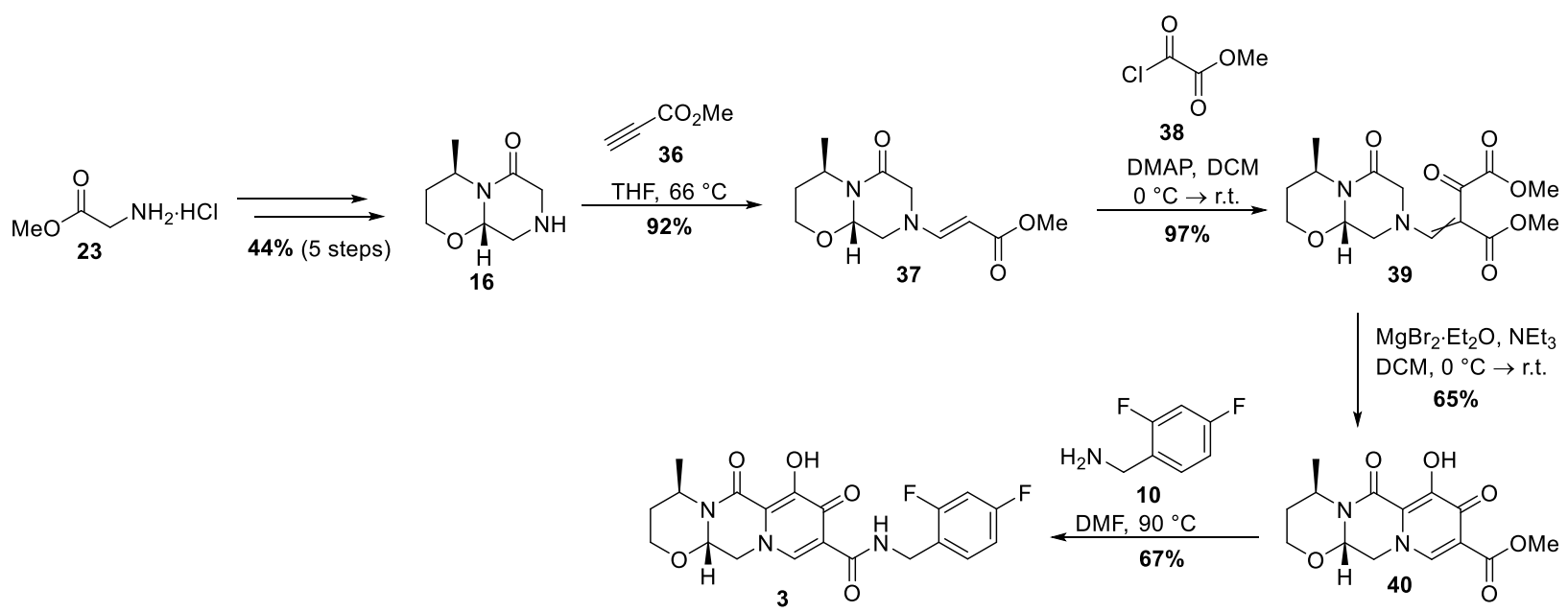

$17 \%$ overall yield ( 9 steps)

Scheme 12: Synthesis of dolutegravir (3) by Jee et al..

Enaminone 39 should be also accessible in a single step by a 1,4-addition from the corresponding enol ether 17. According to a procedure of Jones ${ }^{12}, \mathbf{1 7}$ was prepared from commercially available diethyl oxalacetate sodium salt ( in two steps (Scheme 13). The salt $\mathbf{4 1}$ had to be acidified first to obtain diethyl oxalacetate (42) which was then condensed with triethyl orthoformate (TEOF) in the presence of acetic anhydride $\left(\mathrm{Ac}_{2} \mathrm{O}\right)$. The reaction could be performed in a distillation apparatus and 17 was directly distilled out of the reaction mixture resulting in $72 \%$ yield over two steps.

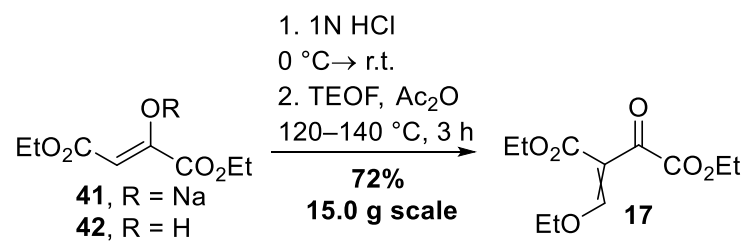

Scheme 13: Synthesis of enol ether $\mathbf{1 7}$ by condensation of $\mathbf{4 2}$ with TEOF and $\mathrm{Ac}_{2} \mathrm{O}$. 
Amine 16 readily underwent 1,4-addition to $\mathbf{4 3}$ in several solvents (DCM, MeCN, EtOH, THF, toluene). Regarding the regioselective cyclization by addressing the keto group of 43, it turned out that using strong bases like $\mathrm{KO}^{t} \mathrm{Bu}, \mathrm{NaOEt}$, or $\mathrm{NaH}$ predominantly led to products derived from a condensation with an ester moiety. Applying the conditions of Jee et al. using a combination magnesium bromide ethyl etherate $\left(\mathrm{MgBr}_{2} \cdot \mathrm{OEt}_{2}\right)$ and triethylamine $\left(\mathrm{NEt}_{3}\right)$, looked more promising and predominantly conversion to ester 18 (81 area\% (254 nm), 35 area\% (315 nm)) could be observed (entry 1, Table 2). Nevertheless, there was still significant byproduct formation according to the HPLC-trace at $315 \mathrm{~nm}$ and ${ }^{1} \mathrm{H}-\mathrm{NMR}$. Furthermore, the reported workup method which consisted of dissolving the crude reaction mixture in sat. $\mathrm{NaHCO}_{3}$-solution, followed by extraction, led to formation of barely soluble magnesium salts which complicated the extraction. Additionally, ester $\mathbf{1 8}$ was partly saponified under these conditions.

For optimization, bases other than $\mathrm{NEt}_{3}$ were investigated first. When diisopropylamine (DIPEA) was used, conversion slightly improved to 91 area\% (254 nm) and 44 area\% (315 nm) (entry 2, Table 2). Using 2,6-lutidine as a base resulted in a similar result to $\mathrm{NEt}_{3}$ (entry 3 ,

Table 2) while $N, N$-dimethylaniline gave only low conversion (entry 4 ,

Table 2). With pyridine, the reaction proceeded much slower, but also cleaner (91 area $\%$ $(254 \mathrm{~nm})$ and 71 area\% $(315 \mathrm{~nm})$ conversion after $65 \mathrm{~h}$ (entry 5,

Table 2). Increasing the equivalents of pyridine (3.0) additionally improved the conversion (entry 6,

Table 2).

Table 2: Screening conditions for building up ring A. 

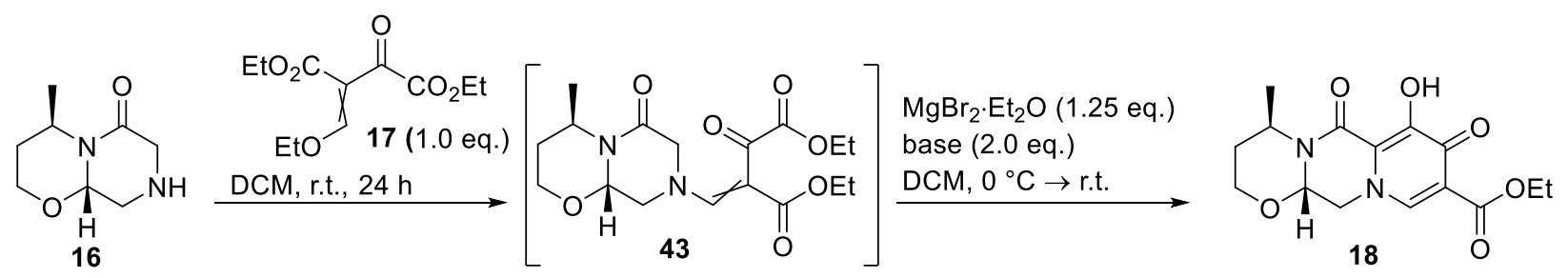

\begin{tabular}{ccccc}
\hline \multirow{2}{*}{ entry } & \multirow{2}{*}{ base } & $\boldsymbol{t}[\mathbf{h}]$ & \multicolumn{2}{c}{ area\% $\mathbf{4 3}^{\boldsymbol{a}}$} \\
\cline { 4 - 5 } & & & $254 \mathrm{~nm}$ & $315 \mathrm{~nm}$ \\
\hline $\mathbf{1}$ & NEt $_{3}$ & 2 & 81 & 35 \\
\hline $\mathbf{2}$ & DIPEA & 2 & 91 & 44 \\
\hline $\mathbf{3}$ & 2,6 -lutidine & 24 & 90 & 37 \\
\hline $\mathbf{4}$ & $N, N$-dimethylaniline & 24 & 48 & 9 \\
\hline $\mathbf{5}$ & pyridine & 2 & 67 & 22 \\
\hline & & 65 & 91 & 71 \\
\hline $\mathbf{6}$ & pyridine $^{b}$ & 65 & 94 & 84
\end{tabular}

${ }^{a}$ Determined by LC-MS. ${ }^{b} 3.0$ eq. were used

For the workup, the reaction mixture was cooled, quenched with $1 \mathrm{~N} \mathrm{HCl}$ and extracted with DCM. When the reaction was performed on a $2 \mathrm{~g}$ scale, a $95 \%$ isolated yield of crude $\mathbf{1 8}$ was obtained. The orange-reddish solid showed a purity of 94 area\% (254 nm) and 87 area\% (315 nm) (Scheme 14).

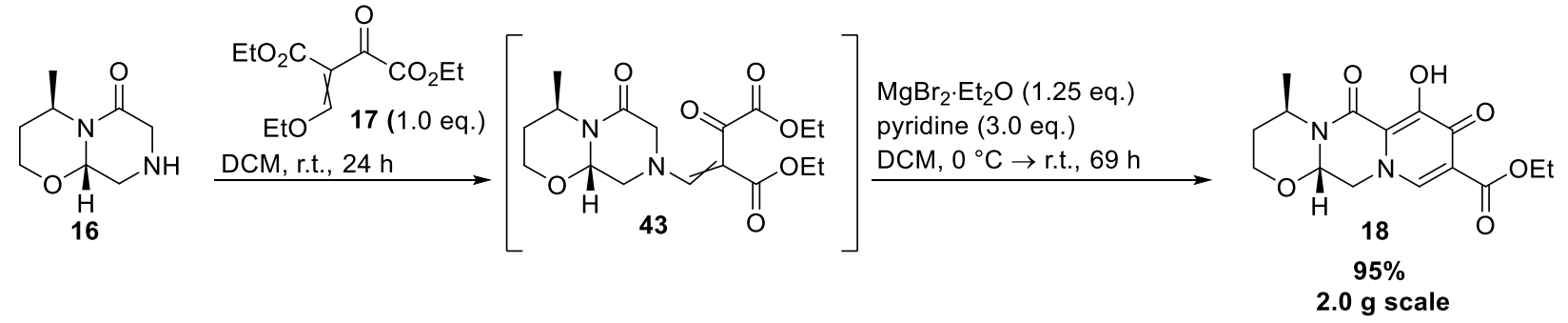

Scheme 14: Synthesis of ester $\mathbf{1 8}$ by one-pot 1,4-addition of amine $\mathbf{1 6}$ with $\mathbf{1 7}$ followed by regioselective cyclization. 
Crude 18 could be washed with ethyl acetate to remove impurities but as some material was lost in this step, crude material was used for the next step. As an alternative procedure for purification, it turned out that saponification furnished acid 19 in pure form. A simple one-pot procedure was developed by adding aqueous $1 \mathrm{~N} \mathrm{NaOH}$ to the DCM-extract of ester 18. After stirring the twophase mixture overnight, $\mathbf{1 8}$ was completely saponified to acid 19. Impurities stayed in the organic phase and acid $\mathbf{1 9}$ precipitated out of the aqueous phase after acidification. Filtration and drying afterwards afforded $\mathbf{1 9}$ as a colorless solid in $72 \%$ yield over three steps (Scheme 15).
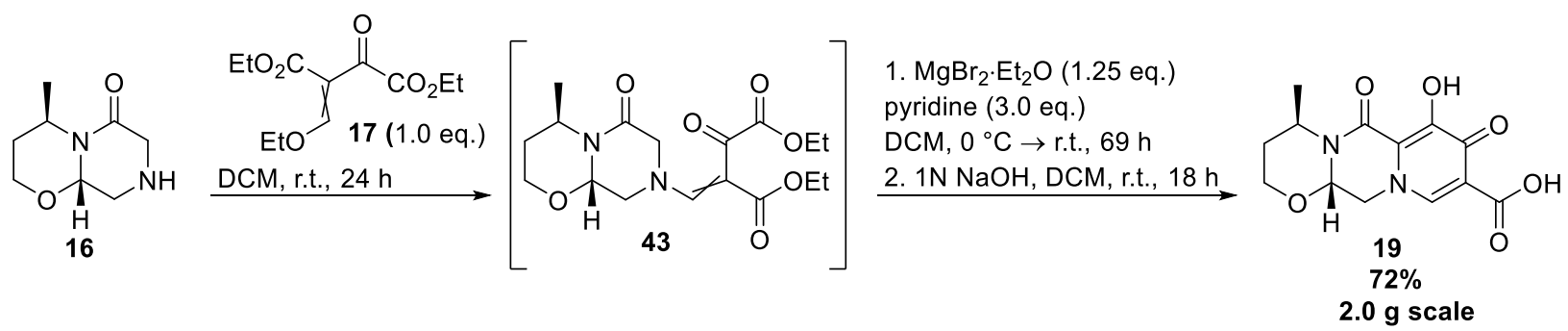

Scheme 15: Synthesis of acid 19 by one-pot 1,4-addition of amine 16 to 43 followed by $\mathrm{MgBr}_{2}-$ mediated regioselective cyclization and saponification.

While investigating the regioselective cyclization, it was also considered to replace $\mathrm{MgBr}_{2} \mathrm{OEt}_{2}$ by cheaper and more widely available $\mathrm{MgCl}_{2}$. From all tested conditions, only heating in $\mathrm{MeCN}$ showed promising results (for more details see supporting information). Conversion to ester $\mathbf{1 8}$ was usually lower (85 area\% (254 nm), 73 area\% (315 nm)). As also partly saponification to acid 19 was observed, it appeared more reasonable to drive the reaction completely towards $\mathbf{1 8}$. After removing $\mathrm{MeCN}$, workup and saponification were performed as mentioned above to furnish a 53\% isolated yield of 19 . 

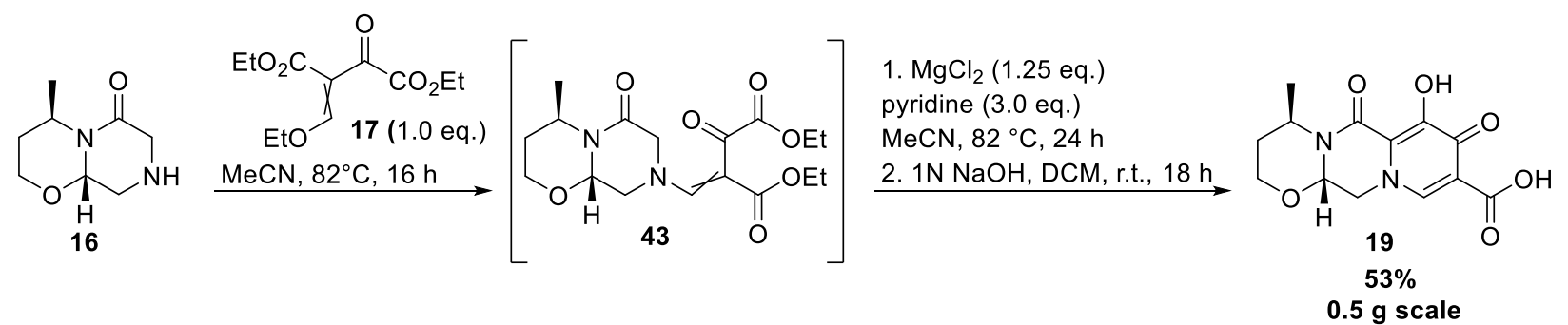

Scheme 16: Synthesis of acid 19 by one-pot 1,4-addition of amine $\mathbf{1 6}$ to $\mathbf{4 3}$ followed by $\mathrm{MgCl}_{2}$ mediated regioselective cyclization and saponification.

\section{Amide coupling}

The aminolysis of an ethyl ester moiety with 2,4-difluorobenzylamine by heating in toluene in the presence of acetic acid has already been reported in literature for other dolutegravir building blocks. ${ }^{7,13}$ The toluene/acetic conditions showed to be appropriate also for ester $\mathbf{1 8}$ and thus were optimized (for more details see supporting information). After heating overnight in the presence of an excess of amine and acetic acid (both 2.5 eq.), full conversion to dolutegravir (3) was detected by LC-MS. It turned out be more efficient when the aqueous workup was omitted. After complete conversion of ester 18, all volatiles were removed in vacuo and the residue was dissolved hot EtOH and treated with sodium hydroxide $(\mathrm{NaOH})$. After filtration and washing, the filtered salt was heated again in EtOH and hot-filtered to increase the purity. After drying, dolutegravir sodium (DTG-Na, 15) was obtained in 70\% isolated yield (HPLC-purity: 99.7\% (254 nm)) (Scheme 17).

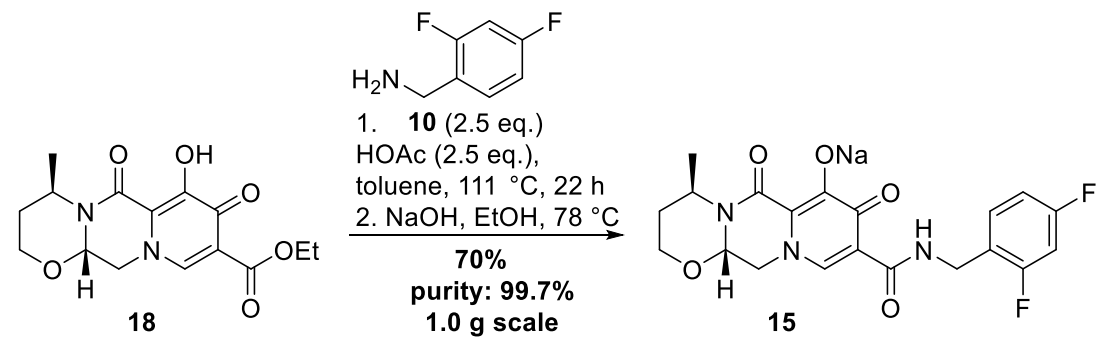

Scheme 17: Synthesis of DTG-Na (15) by aminolysis of crude ester 18 and subsequent salt formation. 
The amide coupling of acid $\mathbf{1 9}$ with amine $\mathbf{1 0}$ has been reported in patent literature. By using the expensive coupling reagent HATU (1-[Bis(dimethylamino)methylene]-1H-1,2,3-triazolo[4,5b]pyridinium 3-oxide hexafluorophosphate), $N$-methylpyrrolidine and DMF as the solvent, 15 was isolated in $55 \%$ yield after purification by preparative HPLC. ${ }^{14}$ The reaction has also been described for preparing bictegravir (4) but 1,1-carbonyldiimidazole (CDI) was used instead as a coupling reagent in this case. ${ }^{15}$ Following this protocol, acid 19 was activated with CDI by stirring for two hours in dimethyl carbonate $(\mathrm{DMC})$ at $80^{\circ} \mathrm{C}$. Amine $\mathbf{1 0}$ was added at r.t. and clean conversion to 3 was detected by LC-MS after two hours. Aqueous workup afforded crude dolutegravir (3) which was converted to the sodium salt as mentioned above giving 15 in $94 \%$ isolated yield showing a HPLC-purity of 99.9\% (254 nm).

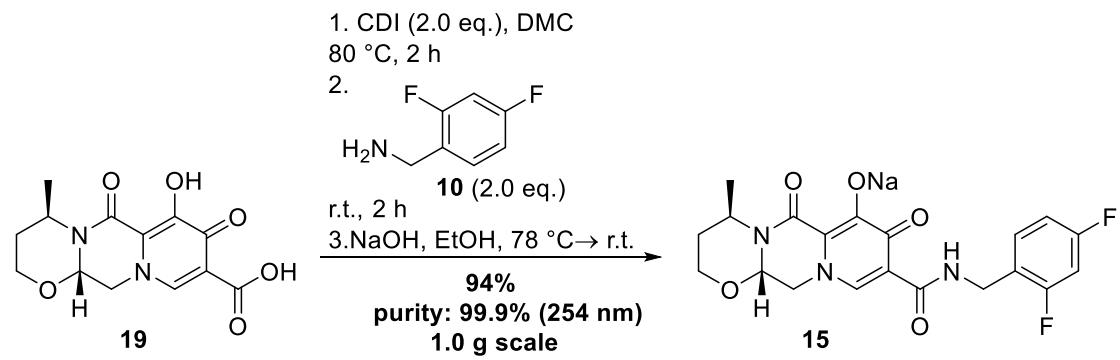

Scheme 18: Synthesis of DTG-Na (15) by amide coupling of acid 19 and subsequent salt formation.

When only 1.7 eq. of CDI was used, incomplete conversion was observed. As a consequence, the final product contained more of non-removable traces of acid $\mathbf{1 9}$ or ester $\mathbf{1 8}$. The reaction was once performed in a smaller scale $(0.3 \mathrm{~g})$ with skipping the aqueous work-up as same as reported for the aminolysis of ester 18. A similar isolated yield (91\%) was obtained but $\mathbf{1 5}$ was slightly less pure $(99.7 \%, 254 \mathrm{~nm})$. 


\section{Conclusions}

A practical synthesis route to dolutegravir sodium starting from 3-(R)-amino-1-butanol(13) was introduced (Scheme 19). First, a new four-step and high-yielding synthesis to ring system BC containing amine 16 was developed. It is noteworthy that the reaction sequence proceeded without significant byproduct formation and no cost-intensive purification steps had to be used. The regioselective cyclization to ring A was carefully optimized and significantly improved. Furthermore, an efficient access to acid 19 was shown. Ester 18 was isolated in a higher yield admittedly but showing a lower purity than acid $\mathbf{1 9}$. Both compounds could be transformed to desired DTG-Na in similar overall yields. Conversion of ester 18 with 1,4-difluorobenzylamine required harsher conditions but less expensive reagents (toluene, acetic acid) while acid 19 showed a cleaner conversion under milder conditions by using CDI as coupling reagent. Ultimately, both transformations represent attractive routes and enable a new synthetic access to DTG-Na. 

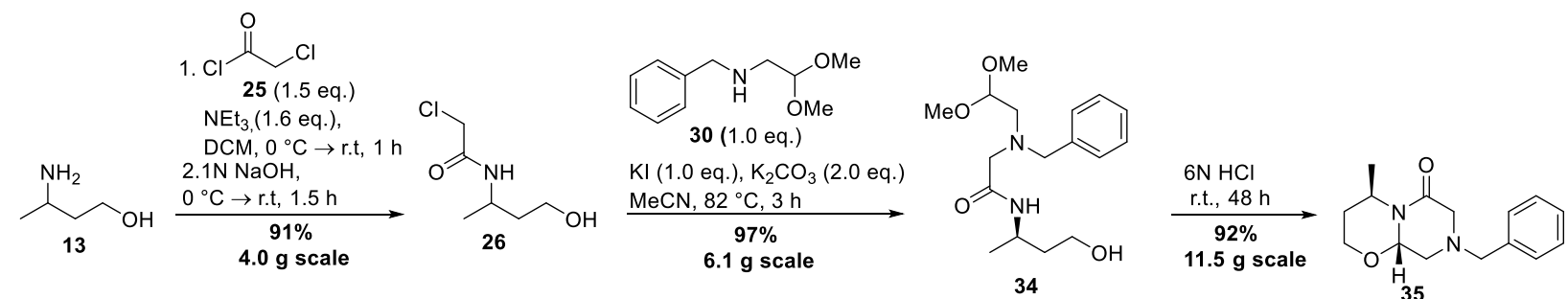

34
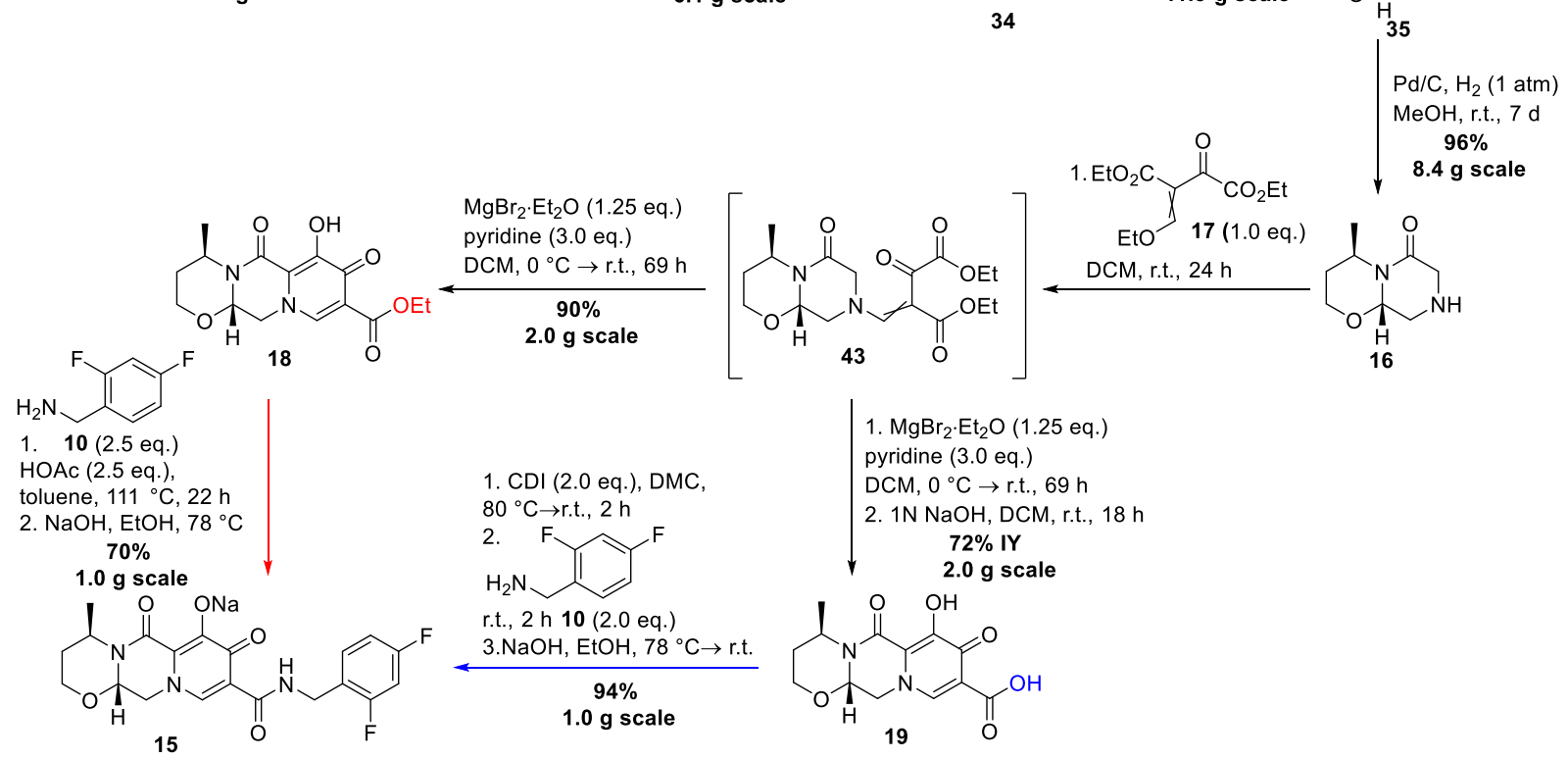

48-51\% IY over 6 steps

purity: $99.7-99.9 \%(254 \mathrm{~nm})$

Scheme 19: Herein reported synthesis of DTG-Na (15).

\section{Experimental section}

All employed chemicals were commercially available and used without prior purification except 2,4-difluorobenzylamine, which was distilled and stored over nitrogen atmosphere. Anhydrous solvents were taken from a solvent purification system and under nitrogen atmosphere. Oven-dried glass ware was dried in an oven at $150{ }^{\circ} \mathrm{C}$ overnight, assembled while still hot, cooled to room temperature and then purged with nitrogen. NMR spectra were recorded on a Bruker Avance-III HD instrument $\left({ }^{1} \mathrm{H}-\mathrm{NMR}: 300 \mathrm{MHz},{ }^{13} \mathrm{C}-\mathrm{NMR}\right.$ : $\left.75 \mathrm{MHz}\right)$ or a Bruker Avance-III HD instrument $\left({ }^{1} \mathrm{H}-\mathrm{NMR}: 400 \mathrm{MHz},{ }^{13} \mathrm{C}-\mathrm{NMR}: 101 \mathrm{MHz},{ }^{19} \mathrm{~F}-\mathrm{NMR}: 377 \mathrm{MHz}\right.$ ) with a $5 \mathrm{~mm}$ BBFO probe. The chemical shifts $\delta$ were expressed in ppm downfield from tetramethylsilane $\left({ }^{1} \mathrm{H}-\mathrm{NMR},{ }^{13} \mathrm{C}-\mathrm{NMR}\right)$. 
Deuterated solvents $\left(\mathrm{CDCl}_{3}, \mathrm{DMSO}-\mathrm{d}_{6}\right)$ served as internal reference. The reported signal splittings were abbreviated as follows: $\mathrm{s}_{\mathrm{b}}=$ broad singlet, $\mathrm{s}=$ singlet, $\mathrm{d}=$ doublet, $\mathrm{t}=$ triplet. Coupling constants $J$ are reported in Hz. ESI-MS spectra were recorded on a 1260-series Infinity II HPLCsystem (Agilent-Technologies) with a binary pump and integrated diode array detector coupled to a LC/MSD Infinitylab LC/MSD (G6125B LC/MSD) mass spectrometer. For high resolution (HR) mass spectra an Agilent 6545 Q-TOF spectrometer and a suitable external calibrant was used. Analytical HPLC was carried out with an Agilent 1260 Infinity system equipped with a binary pump, a diode array detector and LC/MSD InfinityLab LC/MSD (G6125B LC/MSD) mass spectrometer. An Ascentis Express C18 column $\left(2.7 \mu \mathrm{m}, 2.1 \mathrm{~mm}\right.$ x $\left.30 \mathrm{~mm}, 40^{\circ} \mathrm{C}\right)$ or ACE C18 PFP column $\left(3 \mu \mathrm{m}, 4.6 \mathrm{~mm} \times 150 \mathrm{~mm}, 40^{\circ} \mathrm{C}\right)$ with gradient elution using acetonitrile/water $(+0.1 \%$ formic acid) and a flow rate of $1.0 \mathrm{~mL} / \mathrm{min}$ was used. Chiral HPLC was performed on a 1260-series Infinity II HPLC-system (Agilent-Technologies) in normal phase and isocratic mode with $\mathrm{EtOH} / \mathrm{n}$-hexane as mobile phase. A Daicel Chiralpak IF-3 column $(3 \mu \mathrm{m}, 4.6 \mathrm{~mm} \times 250 \mathrm{~mm}$, $40{ }^{\circ} \mathrm{C}$ ) was used for enantiomeric excess determination. Gas chromatography was performed on an Agilent 8890 gas chromatograph equipped with a 5977 GC/MS detector. An Agilent Technologies HP 5MS UI column ( $30 \mathrm{~m} \times 0.25 \mathrm{~mm} \times 0.25 \mu \mathrm{m})$ as stationary phase with helium as carrier gas and a flow rate of $1.2 \mathrm{~mL} / \mathrm{min}$ was used. The following parameters were used: inlet temperature $250{ }^{\circ} \mathrm{C}$, transfer line temperature $250{ }^{\circ} \mathrm{C}$, ion source temperature $230{ }^{\circ} \mathrm{C}$, MSquadrupole temperature $150^{\circ} \mathrm{C}$ and an initial oven temperature of $40^{\circ} \mathrm{C}$ for 2 min with a temperature ramp of $50^{\circ} \mathrm{C} / \mathrm{min}$ to $320^{\circ} \mathrm{C}$ over $5.6 \mathrm{~min}$ followed by $7.4 \mathrm{~min}$ hold. IR-spectroscopy was conducted on a Bruker Tensor 27 FTIR-spectrometer using a diamond ATR unit. Thin-layer chromatography was performed on Merck $F_{254}$ silica gel plates. Spots were visualized with UVlight $(\lambda=254 \mathrm{~nm})$ or stained with appropriate reagents. Melting points are uncorrected and were 
taken by using a Krüss KSP1N digital melting point apparatus. Optical rotations were measured on a Perkin Elmer $241 \mathrm{MC}$ polarimeter.

4-Hydroxybutan-2-one oxime, 44. According to a modified procedure by Budidet et al. ${ }^{16} \mathrm{~A}$ solution of 4-hydroxybutan-2-one ( $95 \%, 5.0 \mathrm{~mL}, 55 \mathrm{mmol}, 1.0$ eq.) in $\mathrm{EtOH}(60 \mathrm{~mL})$ was cooled in an ice-bath. Hydroxylamine hydrochloride ( $4.6 \mathrm{~g}, 66.0 \mathrm{mmol}, 1.2 \mathrm{eq}$.) was added and the $\mathrm{pH}$ was adjusted to 6 by slow addition of aq. sodium hydroxide solution (40 wt $\%)$. The colorless suspension stirred for four hours at r.t. (complete conversion detected by GC-MS) before it was filtered. The solvent was removed in vacuo at $40{ }^{\circ} \mathrm{C}$ and the residue was suspended in EtOAc (50 mL). After drying over $\mathrm{Na}_{2} \mathrm{SO}_{4}$, all volatiles were removed in vacuo at $40{ }^{\circ} \mathrm{C}$ to obtain 44 as a mixture of anti/syn isomers $(5.60 \mathrm{~g}, 54.3 \mathrm{mmol}, 99 \%)$ a colorless viscous oil. $M\left(\mathrm{C}_{4} \mathrm{H}_{9} \mathrm{NO}_{2}\right)$ : $103.12 \mathrm{~g} / \mathrm{mol} . \mathrm{R}_{\mathrm{f}}\left(\mathrm{SiO}_{2}\right):=0.21$ (EtOAc), stained with ninhydrin reagent. IR (ATR): $v=3249$, 2889, 1660, 1427, 1370, 1261, $1050 \mathrm{~cm}^{-1} .{ }^{1} \mathrm{H}-\mathrm{NMR}$, COSY $(400 \mathrm{MHz}$, DMSO-d 6$): \delta=$ 10.26/10.17 (s, 1H,-NOH), 4.62-4.56/4.55-4.48 (m, 1H, -OH), 3.59-3.50 (m, 2H, H-4), 2.41/2.25 (t, $\left.{ }^{3} J=6.8 \mathrm{~Hz}, \mathrm{H}-3\right), 1.78 / 1.73$ (s, 3H, H-1) ppm. ${ }^{13} \mathrm{C}-\mathrm{NMR}$, HSQC, HMBC (100 MHz, DMSO$\left.\mathrm{d}_{6}\right): \delta=154.1 / 153.8$ (C-2), 58.4/57.3 (C-4), 38.8/32.1 (C-3), 20.2/13.5 (C-1) ppm. GC-MS: $m / z=$ 58.1 (100\%). ESI-HRMS: Calcd for $\left[\mathrm{C}_{4} \mathrm{H}_{9} \mathrm{NO}_{2}+\mathrm{H}\right]^{+}: \mathrm{m} / z=104.0706$, found: $m / z=104.0703$.

Rac.-3-Aminobutan-1-ol, rac-13. According to a modified procedure by Budidet et al.. ${ }^{16} \mathrm{~A}$ suspension of 4-hydroxy-2-butanone oxime (44, $8.60 \mathrm{~g}, 83.4 \mathrm{mmol})$ and Raney nickel (10 wt\%) in $\mathrm{MeOH}(70 \mathrm{~mL})$ was hydrogenated in an autoclave for $28 \mathrm{~h}\left(10\right.$ bar $\left.\mathrm{H}_{2}, 45^{\circ} \mathrm{C}\right)$ (reaction control by TLC). The suspension was suction-filtered over celite and the celite cake was washed serveral times with $\mathrm{MeOH}$. All volatiles were removed in vacuo at $40{ }^{\circ} \mathrm{C}$ in order to obtain rac-13 as a colorless oil $(6.91 \mathrm{~g}, 77.6 \mathrm{mmol}, 93 \%)$ which was used for the next step without further purification. $\boldsymbol{M}\left(\mathrm{C}_{4} \mathrm{H}_{11} \mathrm{NO}\right): 89.14 \mathrm{~g} / \mathrm{mol} . \boldsymbol{T}_{\mathbf{b}}: 81-83{ }^{\circ} \mathrm{C}(22 \mathrm{mbar})$, Lit.: $95-97{ }^{\circ} \mathrm{C}(28 \mathrm{mbar})^{17}$. $\mathbf{R}_{\mathbf{f}}$ 
$\left(\mathbf{S i O}_{2}\right)$ ) 0.19 (EtOAc:MeOH:NEt ${ }_{3}=2: 1: 1$ ), stained with ninhydrin-reagent. IR (ATR): $v=3347$, 3280, 3183, 2957, 2924, 2870, 1599, 1455, 1375, $1062 \mathrm{~cm}^{-1} .{ }^{1}$ H-NMR, COSY (400 MHz, $\left.\mathrm{CDCl}_{3}\right): \delta=3.84-3.72(\mathrm{~m}, 2 \mathrm{H}, \mathrm{H}-1), 3.17-3.04(\mathrm{~m}, 1 \mathrm{H}, \mathrm{H}-3), 2.69$ (s, $\left.3 \mathrm{H},-\mathrm{OH} \&-\mathrm{NH}_{2}\right), 1.66-$ $1.57\left(\mathrm{~m}, 1 \mathrm{H}, \mathrm{H}_{\mathrm{a}}-2\right), 1.53-1.42\left(\mathrm{~m}, 1 \mathrm{H}, \mathrm{H}_{\mathrm{b}}-2\right), 1.13\left(\mathrm{~d},{ }^{3} \mathrm{~J}=6.4 \mathrm{~Hz}, 3 \mathrm{H}, \mathrm{H}-4\right)$ ppm. ${ }^{13} \mathbf{C}-\mathbf{N M R}$, HMBC, HSQC (101 MHz, $\left.\mathrm{CDCl}_{3}\right): \delta=62.4$ (C-1), 48.0 (C-3), 39.5 (C-2), 25.8 (C-4) ppm. ESIHRMS: calcd for $[\mathrm{M}+\mathrm{H}]^{+}: m / z=90.0913$, found: $m / z=90.0913$. The spectrometric data are consistent with literature values. ${ }^{18}$

(R)-2-chloro- $N$-(4-hydroxybutan-2-yl)acetamide, 26. In an oven-dried Schlenk-flask, 13 ( $4.00 \mathrm{~g}, 44.9$ mmol, 1.0 eq.) was dissolved in DCM (80 mL). NEt 3 (10.0 mL, $71.8 \mathrm{mmol}, 1.6$ eq.) was added and the solution was cooled in an ice-bath. Chloroacetyl chloride $(\mathbf{2 5}, 5.3 \mathrm{~mL}, 67 \mathrm{mmol}$, 1.5 eq.) was added dropwise over ten minutes, cooling was removed and the dark red-brown solution stirred for one hour at r.t. (complete consumption of $\mathbf{1 3}$ detected by TLC). While cooling, first water $(64 \mathrm{~mL})$ and then $3 \mathrm{~N} \mathrm{NaOH}(32 \mathrm{~mL})$ was added to the reaction mixture. The cooling bath was removed and the two-phasic mixture stirred vigorously for 90 min at r.t. (complete saponification to $\mathbf{2 6}$ detected by GC-MS). The organic phase was separated and extracted with water $(3 \times 40 \mathrm{~mL})$. The combined aqueous phases were cooled and adjusted to $\mathrm{pH}=7-8$ using conc. $\mathrm{HCl}$. The solution was transferred into a Kutscher-Steudel apparatus and extracted continuously with EtOAc for $72 \mathrm{~h}$. The orange organic phase was dried over $\mathrm{Na}_{2} \mathrm{SO}_{4}$, filtered and the solvent was removed in vacuo at $40{ }^{\circ} \mathrm{C} . \mathbf{2 6}$ was obtained as an orange-brown viscous oil (6.73 g, $40.6 \mathrm{mmol}, 91 \%)$ and used for the next step without any further purification. $\boldsymbol{M}$ $\left(\mathrm{C}_{6} \mathrm{H}_{12} \mathrm{ClNO}_{2}\right): 165.63 \mathrm{~g} / \mathrm{mol} \mathbf{\mathbf { R } _ { \mathbf { f } }}\left(\mathbf{S i O}_{2}\right): 0.30$ (EtOAc), stained with ninhydrin reagent. IR (ATR): $v=3280,2936.1651,1543,1056 \mathrm{~cm}^{-1} .{ }^{1} \mathrm{H}-\mathrm{NMR}, \operatorname{COSY}\left(300 \mathrm{MHz}, \mathrm{CDCl}_{3}\right): \delta=6.68\left(\mathrm{~s}_{\mathrm{B}}, 1 \mathrm{H},-\right.$ NH-), 4.27-4.12 (m, 1H, H-2'), 3.71-3.54 (m, 2H, H-4'), 3.01 (s⿱ $, 1 \mathrm{H},-\mathrm{OH}), 1.93-1.80$ (m, 1H, 
$\left.\mathrm{H}_{\mathrm{a}}-3^{\prime}\right), 1.53-1.41\left(\mathrm{~m}, 1 \mathrm{H}, \mathrm{H}_{\mathrm{b}}-3^{\prime}\right), 1.26\left(\mathrm{~d},{ }^{3} \mathrm{~J}=1.3 \mathrm{~Hz}, 3 \mathrm{H}, \mathrm{H}-1^{\prime}\right)$ ppm. ${ }^{13} \mathbf{C}-\mathbf{N M R}, \mathbf{H M B C}$, HSQC (75 MHz, $\left.\mathrm{CDCl}_{3}\right): \delta=166.6(\mathrm{C}-1), 58.9\left(\mathrm{C}-4^{\prime}\right), 43.2\left(\mathrm{C}-2^{\prime}\right), 42.6(\mathrm{C}-2), 39.5$ (C-3'), $20.9(\mathrm{C}-$ 1') ppm. GC-MS: $m / z=120.1(100 \%)$. ESI-HRMS: Calcd for $[\mathrm{M}+\mathrm{H}]^{+}: m / z=166.0629$, found: $m / z=166.0633$.

$\boldsymbol{N}$-benzyl-2,2-dimethoxyethylamine, 30. Method 1: Benzylamine (32, $12.2 \mathrm{~g}, 113 \mathrm{mmol}$, 3.0 eq.) and chloroacetaldehyde-dimethylacetal $(\mathbf{3 1}, 4.71 \mathrm{~g}, 38 \mathrm{mmol}, 1.0 \mathrm{eq}$.$) was dissolved in$ toluene $(50 \mathrm{~mL})$ and heated to reflux for seven days. The suspension was cooled in an ice-bath, filtered and toluene was removed in vacuo at $40{ }^{\circ} \mathrm{C}$. The residue was distilled under vacuum to afford 30 as a colorless liquid $(5.71 \mathrm{~g}, 29.2 \mathrm{mmol}$, 77\%). Method 2: According to a modified procedure from Luu et al. ${ }^{11}$. To a solution of aminoacetaldehyde dimethyl acetal $(\mathbf{8}, 7.91 \mathrm{~g}$, $75.2 \mathrm{mmol})$ in dry methanol $(300 \mathrm{~mL})$, prepared in an oven-dried Schlenk flask under nitrogen atmosphere, was added freshly distilled benzaldehyde $(\mathbf{3 3}, 7.60 \mathrm{~mL}, 75.2 \mathrm{mmol}, 1.0$ eq.) and the solution was stirred for $18 \mathrm{~h} \boldsymbol{M}\left(\mathrm{C}_{11} \mathrm{H}_{17} \mathrm{NO}_{2}\right): 195.26 \mathrm{~g} / \mathrm{mol} . \boldsymbol{T}_{\mathbf{b}}$ : $130-138(13 \mathrm{mbar}){ }^{\circ} \mathrm{C}$, Lit.: $147-$ $149{ }^{\circ} \mathrm{C}(18 \mathrm{mbar})^{19} . \mathbf{R}_{\mathbf{f}}\left(\mathbf{S i O}_{2}\right): 0.35$ (EtOAc 1\% NEt 3$) . \mathbf{I R}(\mathbf{A T R}): v=2934,2830,1454,1192$ 1127, $1056 \mathrm{~cm}^{-1} .{ }^{1} \mathbf{H}-\mathrm{NMR}, \mathbf{C O S Y}\left(300 \mathrm{MHz}, \mathrm{CDCl}_{3}\right): \delta=7.34-7.20(\mathrm{~m}, 5 \mathrm{H}, \mathrm{Ar}-\mathrm{H}), 4.49\left(\mathrm{t},{ }^{3} \mathrm{~J}=\right.$ $5.5 \mathrm{~Hz}, 1 \mathrm{H}, \mathrm{H}-2), 3.81$ (s, 2H, $\left.-\mathrm{CH}_{2} \mathrm{Ar}\right), 3.37$ (s, 6H, 2 x OCH 3$), 2.75$ (d, $\left.{ }^{3} \mathrm{~J}=5.5 \mathrm{~Hz}, 2 \mathrm{H}, \mathrm{H}-1\right)$, 1.54 (sB, $1 \mathrm{H},-\mathrm{NH}-)$ ppm. ${ }^{13} \mathbf{C}-\mathbf{N M R}, \mathbf{H M B C}, \mathbf{H S Q C}\left(75 \mathrm{MHz}, \mathrm{CDCl}_{3}\right): \delta=140.3$ (Ar-C-1), 128.5 (Ar-C-3 \& Ar-C-5, 128.3 (Ar-C-2 \& Ar-C-6), 127.1 (Ar-C-4), 104.1 (C-2) 54.1 (2x - $\mathrm{OCH}_{3}$ ), 54.0 (-CH $2 \mathrm{Ar}), 50.7(\mathrm{C}-1) \mathrm{ppm}$. ESI-MS: $\mathrm{m} / \mathrm{z}=196.1\left(100 \%,[\mathrm{M}+\mathrm{H}]^{+}\right)$. The spectroscopic data are consistent with literature values. ${ }^{11}$

(R)-2-(benzyl(2,2-dimethoxyethyl)amino)- $N$-(4-hydroxybutan-2-yl)acetamide, 34. To a solution of 30 ( $6.11 \mathrm{~g}, 36.9 \mathrm{mmol}$, 1 eq.) in $\mathrm{MeCN}(40 \mathrm{~mL})$ was added while stirring $\mathrm{K}_{2} \mathrm{CO}_{3}$ (10.2 g, $73.8 \mathrm{mmol}, 2.0$ eq.) and KI (6.13 g, $36.9 \mathrm{mmol}, 1.0$ eq.), followed by a solution of 26 
(7.21 g, $36.9 \mathrm{mmol}, 1.0$ eq.) in $\mathrm{MeCN}(40 \mathrm{~mL})$ and additional $\mathrm{MeCN}(130 \mathrm{~mL})$. The suspension was heated to reflux for three hours (full conversion detected by LC-MS, $254 \mathrm{~nm}$ ). The solvent was removed in vacuo at $40^{\circ} \mathrm{C}$ and the salt-like residue was suspended in EtOAc $(150 \mathrm{~mL})$ and water $(210 \mathrm{~mL})$. The mixture was transferred into a separatory funnel and the organic phase was separated. The aqueous phase was extracted with EtOAc $(2 \times 100 \mathrm{~mL})$ and the combined organic phases were dried over $\mathrm{Na}_{2} \mathrm{SO}_{4}$. After removing all volatiles in vacuo at $40{ }^{\circ} \mathrm{C}, \mathbf{3 4}$ was obtained as brown oil (11.63 g, $35.8 \mathrm{mmol}, 97 \%) \cdot \boldsymbol{M}\left(\mathrm{C}_{17} \mathrm{H}_{28} \mathrm{~N}_{2} \mathrm{O}_{4}\right)=324.42 \mathrm{~g} / \mathrm{mol}$. $[\boldsymbol{\alpha}]_{589}^{19}=-29.6\left(\mathrm{CHCl}_{3}\right.$, $\mathrm{c}=10 \mathrm{mg} / \mathrm{mL}) . \mathbf{R}_{\mathbf{f}}\left(\mathbf{S i O}_{2}\right): 0.32\left(\mathrm{EtOAc}+2 \% \mathrm{NEt}_{3}\right) . \mathbf{I R}(\mathbf{A T R}): v=3324,2933,2833,1649$, 1529, 1453, 1120, $1063 \mathrm{~cm}^{-1} .{ }^{1} \mathbf{H}-\mathbf{N M R}, \mathbf{C O S Y}\left(300 \mathrm{MHz}, \mathrm{CDCl}_{3}\right): \delta=7.59(\mathrm{~m}, 1 \mathrm{H},-\mathrm{NH}-), 7.38-$ 7.22 (m, 5H, Ar-H), 4.39 (t, $\left.{ }^{3} J=5.3 \mathrm{~Hz}, \mathrm{H}-2^{\prime \prime}\right), 4.20-4.04$ (m, 1H, H-2'), 3.92-3.80 (m, 1H, -OH), $3.72\left(\mathrm{~s}, 2 \mathrm{H}, \mathrm{PhCH}_{2}-\right), 3.59-3.46\left(\mathrm{~m}, 1 \mathrm{H}, \mathrm{H}_{\mathrm{a}}-4^{\prime}\right), 3.35\left(\mathrm{~s}, 3 \mathrm{H},-\mathrm{OCH}_{3}\right), 3.33\left(\mathrm{~s}, 3 \mathrm{H},-\mathrm{OCH}_{3}\right), 3.33-$ $3.30\left(\mathrm{~m}, 1 \mathrm{H}, \mathrm{H}_{\mathrm{b}}-4^{\prime}\right), 3.20\left(\mathrm{~d},{ }^{4} J=1.8 \mathrm{~Hz}, 2 \mathrm{H}, \mathrm{H}-2\right), 2.71\left(\mathrm{dd},{ }^{3} J=5.3 \mathrm{~Hz},{ }^{4} J=1.1 \mathrm{~Hz}, 2 \mathrm{H}, \mathrm{H}-1^{\prime \prime}\right)$, $1.89-1.76\left(\mathrm{~m}, 1 \mathrm{H}, \mathrm{H}_{\mathrm{a}}-3^{\prime}\right), 1.33-1.24\left(\mathrm{~m}, 1 \mathrm{H}, \mathrm{H}_{\mathrm{b}}-3^{\prime}\right), 1.22\left(\mathrm{~d},{ }^{3} \mathrm{~J}=6.7 \mathrm{~Hz}, 3 \mathrm{H}, \mathrm{H}-1^{\prime}\right)$ ppm. ${ }^{13} \mathbf{C}-$ NMR, HMBC, HSQC (75 MHz, $\left.\mathrm{CDCl}_{3}\right): \delta=172.0(\mathrm{C}=\mathrm{O}), 138.0$ (Ar-C), 129.0 (Ar-C), 128.7 (Ar-C), 127.8 (Ar-C), $102.9\left(\mathrm{C}-2^{\prime \prime}\right), 60.7\left(\mathrm{PhCH}_{2}-\right), 58.6\left(\mathrm{C}-4^{\prime}\right), 58.6(\mathrm{C}-2), 57.3$ (C-1'), 54.1 ($\left.\mathrm{OCH}_{3}\right), 53.9\left(-\mathrm{OCH}_{3}\right), 41.4\left(\mathrm{C}-2^{\prime}\right), 40.5\left(\mathrm{C}-3^{\prime}\right), 21.2\left(\mathrm{C}^{\prime} 1^{\prime}\right)$ ppm. ESI-HRMS: Calcd for [M+H] ${ }^{+}$: $m / z=325.2122$, found: $m / z=325.2130$.

(4R,9aS)-8-Benzyl-4-methylhexahydro-2H,6H-pyrazino[2,1-b][1,3] oxazin-6-one,

35.

Acetal 34 (11.53 g, $35.5 \mathrm{mmol})$ was suspended in water $(160 \mathrm{~mL})$ and cooled in an ice-bath. Conc. $\mathrm{HCl}(160 \mathrm{~mL})$ was added through a dropping funnel over 15 min while stirring. Cooling was removed and the slightly yellow solution stirred at r.t. for $48 \mathrm{~h}$ (complete conversion by LC-MS at $254 \mathrm{~nm})$. The solution was cooled again in an ice-bath and sodium hydroxide pellets $(75 \mathrm{~g})$ were added in small portions over two hours, followed by sodium bicarbonate powder $(4 \mathrm{~g})$ in order to 
adjust the $\mathrm{pH}$ to $7-8$. While approaching the desired $\mathrm{pH}, \mathbf{3 5}$ started precipitating, resulting in a murky beige suspension. EtOAc $(300 \mathrm{~mL})$ was added while stirring and the mixture was transferred into a separating funnel. The organic phase was separated and the aqueous phase was extracted with EtOAc $(2 \times 200 \mathrm{~mL})$. The combined organic phases were dried over $\mathrm{Na}_{2} \mathrm{SO}_{4}$, filtered and the solvent was removed in vacuo at $40{ }^{\circ} \mathrm{C}$. Crude 35 was obtained as a thick orangebrown oil ( $8.49,32.6 \mathrm{mmol}, 92 \%, \geq 99.8 \%$ ee according to chiral HPLC). Racemic 35 was synthesized analogously from rac-13. $\boldsymbol{M}\left(\mathrm{C}_{15} \mathrm{H}_{20} \mathrm{~N}_{2} \mathrm{O}_{2}\right)=260.34 \mathrm{~g} / \mathrm{mol} .[\boldsymbol{\alpha}]_{589}^{19}:-46.1\left(\mathrm{CHCl}_{3}, \mathrm{c}\right.$ $=10 \mathrm{mg} / \mathrm{mL}) . \mathbf{R}_{\mathbf{f}}\left(\mathbf{S i O}_{2}\right): 0.32$ (EtOAc). IR (ATR): $v=2969,2860,1653,1455,1328,1197,1095$, $1068 \mathrm{~cm}^{-1} .{ }^{1} \mathbf{H}-\mathbf{N M R}, \mathbf{C O S Y}\left(300 \mathrm{MHz}, \mathrm{CDCl}_{3}\right): \delta=7.36-7.23(\mathrm{~m}, 5 \mathrm{H}, \mathrm{Ar}-\mathrm{H}), 4.97-4.86(\mathrm{~m}, 2 \mathrm{H}$, H-4 \& H-9a), 3.93-3.81 (m, 2H, H-2), 3.57 (d, $\left.{ }^{2} J=13.1 \mathrm{~Hz}, 1 \mathrm{H},-\mathrm{NCH}_{\mathrm{a}} \mathrm{Ar}\right), 3.54\left(\mathrm{~d},{ }^{2} J=13.1 \mathrm{~Hz}\right.$, $\left.1 \mathrm{H},-\mathrm{NCH}_{\mathrm{b}} \mathrm{Ar}\right), 3.24\left(\mathrm{dd},{ }^{2} J=16.0 \mathrm{~Hz},{ }^{4} J=1.9 \mathrm{~Hz}, 1 \mathrm{H}, \mathrm{H}_{\mathrm{a}}-7\right), 3.02\left(\mathrm{dd},{ }^{2} J=16.3 \mathrm{~Hz},{ }^{4} J=0.8 \mathrm{~Hz}\right.$, $\left.1 \mathrm{H}, \mathrm{H}_{\mathrm{b}}-7\right), 2.97\left(\mathrm{ddd},{ }^{2} J=12.0 \mathrm{~Hz},{ }^{3} J=4.9 \mathrm{~Hz},{ }^{4} J=1.9 \mathrm{~Hz}, 1 \mathrm{H}, \mathrm{H}_{\mathrm{a}}-9\right), 2.44\left(\mathrm{ddd},{ }^{2} J=12.0 \mathrm{~Hz},{ }^{3} J\right.$ $\left.=6.7 \mathrm{~Hz},{ }^{4} J=0.8 \mathrm{~Hz}, 1 \mathrm{H}, \mathrm{H}_{\mathrm{b}}-9\right), 2.19-2.04\left(\mathrm{~m}, 1 \mathrm{H}, \mathrm{H}_{\mathrm{a}}-3\right), 1.43-1.34\left(\mathrm{~m}, 1 \mathrm{H}, \mathrm{H}_{\mathrm{b}}-3\right), 1.27\left(\mathrm{~d},{ }^{3} J=\right.$ $\left.7.1 \mathrm{~Hz}, 4-\mathrm{CH}_{3}\right)$ ppm. ${ }^{13} \mathrm{C}-\mathrm{NMR}$, HSQC, HMBC $\left(75 \mathrm{MHz}, \mathrm{CDCl}_{3}\right): \delta=166.3$ (C-6), 136.3 (ArH), 129.4 (Ar-H), 128.6 (Ar-H), 127.7 (Ar-H), 79.3 (C-9a), 62.8 (C-2), $61.6\left(-\mathrm{NCH}_{2} \mathrm{Ar}\right), 57.5$ (C7), 54.3 (C-9), 41.7 (C-4), $29.8(\mathrm{C}-3), 15.9\left(-\mathrm{CH}_{3}\right) \mathrm{ppm}$. ESI-HRMS: calcd for $[\mathrm{M}+\mathrm{H}]^{+}: \mathrm{m} / \mathrm{z}=$ 261.1594, found: $m / z=261.1598$.

(4R,9aS)-4-methylhexahydro-2H,6H-pyrazino[2,1-b][1,3]oxazin-6-one, 16. A solution of oxazinone 35 ( $8.44 \mathrm{~g}, 324 \mathrm{mmol})$ in $\mathrm{MeOH}(120 \mathrm{~mL})$ was degassed for ten minutes by purging with nitrogen. Palladium ( $10 \%$ on carbon, $0.85 \mathrm{~g}$ ) was added and the mixture was purged with hydrogen three times. The mixture stirred under hydrogen atmosphere for seven days (complete conversion by LC-MS at $254 \mathrm{~nm}$ ). After purging for ten minutes with nitrogen, the mixture was suction-filtered over celite and washed several times with $\mathrm{MeOH}$. All volatiles were removed in 
vacuo at $40{ }^{\circ} \mathrm{C}$. Crude 16 was obtained as a viscous yellow-orange oil (5.31 g, $\left.31.2 \mathrm{mmol}, 96 \%\right)$ which solidified to a slight yellowish solid after a while. $\mathbf{1 6}$ was used for the next step without further purification. $\boldsymbol{M}\left(\mathrm{C}_{8} \mathrm{H}_{14} \mathrm{~N}_{2} \mathrm{O}_{2}\right): 170.21 \mathrm{~g} / \mathrm{mol} . \boldsymbol{T}_{\mathrm{m}}: 56-61{ }^{\circ} \mathrm{C} ; 79-83{ }^{\circ} \mathrm{C}$ (rac.). $[\boldsymbol{\alpha}]_{589}^{19}:-103.1$ $\left(\mathrm{CHCl}_{3}, \mathrm{c}=10 \mathrm{mg} / \mathrm{mL}\right) . \mathbf{R}_{\mathbf{f}}\left(\mathbf{S i O}_{2}\right): 0.31\left(\mathrm{EtOAc}+10 \% \mathrm{MeOH}+5 \% \mathrm{NEt}_{3}\right)$, stained with ninhydrin reagent. IR (ATR): $v=3307,2968,2865,1643,1451,1324,1193,1080,1064 \mathrm{~cm}^{-1} .{ }^{1} \mathrm{H}-\mathbf{N M R}$, $\operatorname{COSY}\left(300 \mathrm{MHz}, \mathrm{CDCl}_{3}\right): \delta=5.04-4.92(\mathrm{~m}, 1 \mathrm{H}, \mathrm{H}-4), 4.85-4.80$ (m, 1H, H-9a), 4.00-3.85 (m, $1 \mathrm{H}, \mathrm{H}-2), 3.48\left(\mathrm{~d},{ }^{2} J=17.3 \mathrm{~Hz}, 1 \mathrm{H}, \mathrm{H}_{\mathrm{a}}-7\right), 3.38\left(\mathrm{~d},{ }^{2} J=17.3 \mathrm{~Hz}, 1 \mathrm{H}, \mathrm{H}_{\mathrm{b}}-7\right), 3.14\left(\mathrm{dd},{ }^{2} J=13.6 \mathrm{~Hz}\right.$, $\left.{ }^{3} J=3.8 \mathrm{~Hz} 1 \mathrm{H}, \mathrm{H}_{\mathrm{a}}-9\right), 2.97\left(\mathrm{dd},{ }^{2} J=13.6 \mathrm{~Hz},{ }^{3} J=4.3 \mathrm{~Hz} 1 \mathrm{H}, \mathrm{H}_{\mathrm{b}}-9\right), 2.16-2.01\left(\mathrm{~m}, 1 \mathrm{H},\left(\mathrm{H}_{\mathrm{a}}-3\right)\right.$, $1.78\left(\mathrm{~s}_{\mathrm{B}}, 1 \mathrm{H},-\mathrm{NH}-\right), 1.41-1.32\left(\mathrm{~m}, 1 \mathrm{H}, \mathrm{H}_{\mathrm{b}}-3\right), 1.26\left(\mathrm{t},{ }^{3} \mathrm{~J}=7.1 \mathrm{~Hz}, 3 \mathrm{H},-\mathrm{CH}_{3}\right)$ ppm. ${ }^{13} \mathbf{C}-\mathbf{N M R}$, HSQC, HMBC (75 MHz, CDCl $)$ ): $\delta=167.8$ (C-6), 78.8 (C-9a), 63.0 (C-2), 50.3 (C-7), 48.1 (C9), $42.2(\mathrm{C}-4), 29.9(\mathrm{C}-3), 15.9\left(-\mathrm{CH}_{3}\right) \mathrm{ppm}$. ESI-MS: $m / z=171.1\left(100 \%,[\mathrm{M}+\mathrm{H}]^{+}\right)$. The spectrometric data are consistent with literature values. ${ }^{10}$

Diethyl-(2E/Z)-2-(ethoxymethyliden)-3-oxobutandioate, 17. Diethyl oxalacetate sodium salt (41, 95\%, $15.0 \mathrm{~g}, 67.8 \mathrm{mmol})$ was weighed into an Erlenmeyer flask and suspended in EtOAc $(90 \mathrm{~mL})$. The suspension was cooled in an ice bath and $1 \mathrm{~N} \mathrm{HCl}(86 \mathrm{~mL})$ was added while stirring. After all of the salt was dissolved, the biphasic murky mixture was transferred into a separatory funnel. The organic phase was separated and the aqueous phase was extracted with EtOAc $(2 \mathrm{x}$ $45 \mathrm{~mL}$ ). The combined organic phases were dried over $\mathrm{Na}_{2} \mathrm{SO}_{4}$, filtered and the solvent was removed in vacuo at $30^{\circ} \mathrm{C}$. To the orange-brown oily residue $(13.1 \mathrm{~g})$ was added triethyl orthoformate (20.7 mL, $122 \mathrm{mmol}, 1.8$ eq.) and acetic anhydride (17.9 mL, $190 \mathrm{~mL}, 2.8$ eq.). The flask was equipped with a distillation apparatus and the solution was heated for one hour to $120^{\circ} \mathrm{C}$, for one hour to $130{ }^{\circ} \mathrm{C}$ and for one hour to $140{ }^{\circ} \mathrm{C}$, while a colorless clear liquid was distilled off. After cooling down, distillation under high vacuum afforded $\mathbf{1 7}$ as a yellow clear liquid (12.0 g, 
$49.2 \mathrm{mmol}, 72 \%) . \boldsymbol{M}\left(\mathrm{C}_{11} \mathrm{H}_{16} \mathrm{O}_{6}\right): 244.24 \mathrm{~g} / \mathrm{mol} . \boldsymbol{T}_{\mathbf{b}}: 116-120^{\circ} \mathrm{C}(0.45 \mathrm{mbar})$, Lit.: $155-160{ }^{\circ} \mathrm{C}$ $\left(1.3 \mathrm{mbar}^{12} . \mathbf{R}_{\mathbf{f}}\left(\mathbf{S i O}_{2}\right): 0.15 \& 0.81\right.$ (EtOAc). IR (ATR): $v=2987,2937,1359,1256,1177$ $1019 \mathrm{~cm}^{-1} .{ }^{1} \mathrm{H}-\mathrm{NMR}, \operatorname{COSY}\left(300 \mathrm{MHz}, \mathrm{CDCl}_{3}\right): \delta=7.90(\mathrm{~s}, 1 \mathrm{H},=\mathrm{CH}-), 7.88\left(\mathrm{~s}, 1 \mathrm{H},=\mathrm{CH}^{\prime}-\right)$, $4.40-4.32\left(\mathrm{~m}, 2 \mathrm{H},=\mathrm{CHOCH}_{2}-\right), 4.40-4.32\left(\mathrm{~m}, 2 \mathrm{H},=\mathrm{CHOCH}_{2}^{\prime}-\right), 4.32-4.27(\mathrm{~m}, 2 \mathrm{H}, \mathrm{O}=\mathrm{C}-4-$ $\left.\mathrm{OCH}_{2}-\right), 4.32-4.27\left(\mathrm{~m}, 2 \mathrm{H}, \mathrm{O}=\mathrm{C}-4^{\prime}-\mathrm{OCH}_{2}-\right), 4.27-4.18\left(\mathrm{~m}, 2 \mathrm{H}, \mathrm{O}=\mathrm{C}-1-\mathrm{OCH}_{2}-\right), 4.27-4.18(\mathrm{~m}$, $\left.2 \mathrm{H}, \mathrm{O}=\mathrm{C}-1^{\prime}-\mathrm{OCH}_{2}-\right), 1.44\left(\mathrm{t},{ }^{3} \mathrm{~J}=7.2 \mathrm{~Hz}, 3 \mathrm{H},=\mathrm{CHOCH}_{2} \mathrm{CH}_{3}\right), 1.43 \quad\left(\mathrm{t},{ }^{3} \mathrm{~J}=7.2 \mathrm{~Hz}\right.$, $\left.3 \mathrm{H}=\mathrm{CHOCH}_{2} \mathrm{CH}_{3}^{\prime}\right), 1.36\left(\mathrm{t},{ }^{3} \mathrm{~J}=7.2 \mathrm{~Hz}, 3 \mathrm{H}, \mathrm{O}=\mathrm{C}-4-\mathrm{OCH}_{2} \mathrm{CH}_{3}\right), 1.35\left(\mathrm{t},{ }^{3} \mathrm{~J}=7.2 \mathrm{~Hz}, 3 \mathrm{H}, \mathrm{O}=\mathrm{C}-4-\right.$ $\left.\mathrm{OCH}_{2} \mathrm{CH}_{3}^{\prime}\right), 1.28\left(\mathrm{t},{ }^{3} \mathrm{~J}=7.2 \mathrm{~Hz}, 3 \mathrm{H}, \mathrm{O}=\mathrm{C}-1-\mathrm{OCH}_{2} \mathrm{CH}_{3}\right), 1.27\left(\mathrm{t},{ }^{3} J=7.2 \mathrm{~Hz}, 3 \mathrm{H}, \mathrm{O}=\mathrm{C}-1-\right.$ $\left.\mathrm{OCH}_{2} \mathrm{CH}_{3}^{\prime}\right)$ ppm. ${ }^{13} \mathrm{C}-\mathrm{NMR}, \mathbf{H S Q C}, \mathbf{H M B C}\left(75 \mathrm{MHz}, \mathrm{CDCl}_{3}\right): \delta=185.2(\mathrm{C}-3), 183.2\left(\mathrm{C}-3^{\prime}\right)$, 170.1 (=CH-), 170.0 (=CH'-), 165.2 (C-1), 164.2 (C-4), 164.0 (C-4'), 163.5 (C-1'), $109.6(\mathrm{C}-2)$, $108.3\left(\mathrm{C}-2^{\prime}\right), 74.7\left(=\mathrm{CH}-\mathrm{O}-\mathrm{CH}_{2}-\right), 74.6\left(=\mathrm{CH}-\mathrm{O}-\mathrm{C}^{\prime} \mathrm{H}_{2}-\right), 62.2\left(\mathrm{O}=\mathrm{C}-1-\mathrm{OCH}_{2}-\right), 62.0\left(\mathrm{O}=\mathrm{C}-1^{\prime}-\right.$ $\left.\mathrm{OCH}_{2}-\right), \quad 61.1 \quad\left(\mathrm{O}=\mathrm{C}-4-\mathrm{OCH}_{2}-\right), \quad 61.0 \quad\left(\mathrm{O}=\mathrm{C}^{-} 4^{\prime}-\mathrm{OCH}_{2}-\right), \quad 15.4 \quad\left(=\mathrm{CHOCH}_{2} \mathrm{CH}_{3}\right), \quad 15.4$ $\left(=\mathrm{CHOCH}_{2} \mathrm{C}^{\prime} \mathrm{H}_{3}\right), 14.3\left(\mathrm{O}=\mathrm{C}-1-\mathrm{OCH}_{2} \mathrm{CH}_{3}\right), 14.2\left(\mathrm{O}=\mathrm{C}-1^{\prime}-\mathrm{OCH}_{2} \mathrm{CH}_{3}\right), 14.1\left(\mathrm{O}=\mathrm{C}-4-\mathrm{OCH}_{2} \mathrm{CH}_{3}\right)$, $14.1\left(\mathrm{O}=\mathrm{C}-4^{\prime}-\mathrm{OCH}_{2} \mathrm{CH}_{3}\right)$ ppm. ESI-MS: $m / z=217.1\left(100 \%,[\mathrm{M}-\mathrm{Et}+\mathrm{H}]^{+}\right)$. Ethyl enol ether hydrolyzes during the LC-MS run to the free enol. The spectrometric data are consistent with literature values. ${ }^{12}$

Ethyl

(4R,12aS)-7-hydroxy-4-methyl-6,8-dioxo-3,4,6,8,12,12a-hexahydro-2Hpyrido[1',2':4,5]pyrazino[2,1-b][1,3]oxazine-9-carboxylate, 18. Amine 16 (2.00 g, $11.8 \mathrm{mmol}$, 1.0 eq.) was added in a single portion to a solution of enol ether $17(2.87 \mathrm{~g}, 11.8 \mathrm{mmol}, 1.0 \mathrm{eq}$.$) in$ dry DCM $(80 \mathrm{~mL})$ which was prepared in an oven-dried Schlenk flask under nitrogen atmosphere. The yellow-greenish solution was stirred at r.t. for $24 \mathrm{~h}$ (full conversion of $\mathbf{1 7}$ detected by LC-MS, $254 / 315 \mathrm{~nm})$ before it was cooled in an ice-bath. $\mathrm{MgBr}_{2} \cdot \mathrm{OEt}_{2}(3.79 \mathrm{~g}, 14.7 \mathrm{mmol}, 1.25$ eq.) was added all at once under nitrogen reverse flow and the suspension was stirred for 10 min before dry 
pyridine $(2.8 \mathrm{~mL}, 35 \mathrm{mmol}, 3.0$ eq.) was dripped into the yellowish suspension within two minutes. A clear orange-red solution formed immediately which was stirred at r.t. for three days (full conversion of $\mathbf{4 3}$ detected by LC-MS, 254/315 nm). The suspension was cooled in an ice bath and $1 \mathrm{~N} \mathrm{HCl}(60 \mathrm{~mL})$ was added while stirring. The mixture was transferred into a separatory funnel, vigorously shaken and the organic phase was separated. The aqueous phase was extracted with DCM $(2 \times 50 \mathrm{~mL})$ and combined organic phases were dried over $\mathrm{Na}_{2} \mathrm{SO}_{4}$, filtered and the solvent was removed in vacuo at $40{ }^{\circ} \mathrm{C}$. Crude $\mathbf{1 8}$ was obtained as an orange fluffy solid $(3.61 \mathrm{~g}$, $10.6 \mathrm{mmol}, 90 \%$, HPLC-purity: 94\% (254 nm), 87\% (315 nm)) and used for the next step without further purification. To obtain pure material, crude $\mathbf{1 8}$ was heated in EtOAc $(0.1 \mathrm{~g} / 2 \mathrm{~mL})$, cooled down to r.t. first, then to $-24{ }^{\circ} \mathrm{C}$ (freezer). The solid was filtered off, washed with ice-cold EtOAc and dried in vacuo at $40{ }^{\circ} \mathrm{C} . \boldsymbol{M}\left(\mathrm{C}_{15} \mathrm{H}_{18} \mathrm{~N}_{2} \mathrm{O}_{6}\right): 322.32 \mathrm{~g} / \mathrm{mol} . \boldsymbol{T}_{\mathbf{m}}=90-96{ }^{\circ} \mathrm{C}$ (sintering to an orange resin), $104-106^{\circ} \mathrm{C}$ (resin melts to a yellow-greenish liquid). $[\alpha]_{589}^{21}=-35.6\left(\mathrm{CHCl}_{3}, \mathrm{c}=\right.$ $10 \mathrm{mg} / \mathrm{mL})) . \mathbf{R}_{\mathbf{f}}\left(\mathbf{C}_{\mathbf{1 8}}-\mathbf{S i O}_{2}\right): 0.58\left(\mathrm{EtOH}: \mathrm{H}_{2} \mathrm{O}=1: 1,+10 \% \mathrm{HOAc}\right) . \mathbf{I R}(\mathbf{A T R}): v=2979,1725$, 1632, 1452, 1282, 1262, 1181, 1090, $1048 \mathrm{~cm}^{-1} .{ }^{1} \mathbf{H}-\mathbf{N M R}, \mathbf{C O S Y}\left(300 \mathrm{MHz}, \mathrm{CDCl}_{3}\right): \delta=12.33$ (sB, 1H, -OH), 7.91 (s, 1H, H-10), 5.40-5.28 (m, 1H, H-12a), 5.00-4.87 (m, 1H, H-4), 4.40-4.19 (m, 3H, $\mathrm{H}_{\mathrm{a}}-12$ \& $\left.-\mathrm{OCH}_{2}-\right), 4.12-3.91\left(\mathrm{~m} 3 \mathrm{H}, \mathrm{H}-2\right.$ \& $\left.\mathrm{H}_{\mathrm{b}}-12\right), 2.29-2.11\left(\mathrm{~m}, 1 \mathrm{H}, \mathrm{H}_{\mathrm{a}}-3\right), 1.60-1.49$ (m, $\left.1 \mathrm{H}, \mathrm{H}_{\mathrm{b}}-3\right), 1.43\left(\mathrm{t},{ }^{3} \mathrm{~J}=7.1 \mathrm{~Hz}, 3 \mathrm{H}, 4-\mathrm{CH}_{3}\right), 1.33\left(\mathrm{t},{ }^{3} \mathrm{~J}=7.0 \mathrm{~Hz}, 3 \mathrm{H},-\mathrm{OCH}_{2} \mathrm{CH}_{3}\right)$ ppm. ${ }^{13} \mathbf{C}-$ NMR, HMBC, HSQC (75 MHz, $\mathrm{CDCl}_{3}$ ): $\delta=169.8$ (C-8), 164.3 (-COOEt), 162.5 (C-6), 156.5 (C-7), 141.5 (C-10), 115.3 (C-6a), 114.8 (C-9), 76.4 (C-12a), 62.8 (C-2), $61.1\left(-\mathrm{OCH}_{2}\right), 52.6$ (C12), $44.8(\mathrm{C}-4), 29.5(\mathrm{C}-3), 15.7\left(4-\mathrm{CH}_{3}\right), 14.4\left(-\mathrm{OCH}_{2} \mathrm{CH}_{3}\right)$ ppm. ESI-HRMS: calcd for $[\mathrm{M}+\mathrm{H}]^{+}$: $m / z=323.1238$, found: $m / z=323.1227$.

(4R)-7-hydroxy-4-methyl-6,8-dioxo-3,4,6,8,12,12a-hexahydro-2Hpyrido[1',2':4,5]pyrazino[2,1-b][1,3]oxazine-9-carboxylic acid, 19. Method 1: A solution of 
enol ether 17 (2.87 g, $11.8 \mathrm{mmol}, 1.0$ eq.) in dry DCM $(80 \mathrm{~mL})$ was prepared in an oven-dried Schlenk flask under nitrogen atmosphere. Amine 16 (2.00 g, $11.8 \mathrm{mmol}, 1.0$ eq.) was added all at once and the yellow-greenish solution stirred at r.t. for $24 \mathrm{~h}$ (full conversion of $\mathbf{1 7}$ detected by LCMS, $254 / 315 \mathrm{~nm})$ and then cooled in an ice-bath. $\mathrm{MgBr}_{2} \cdot \mathrm{OEt}_{2}(3.79 \mathrm{~g}, 14.7 \mathrm{mmol}, 1.25$ eq. $)$ was added all at once under nitrogen reverse flow and the suspension was stirred for $10 \mathrm{~min}$ before dry pyridine $(2.8 \mathrm{~mL}, 35 \mathrm{mmol}, 3.0$ eq.) was dripped into the yellowish suspension within two minutes. A clear orange-red solution formed immediately which was stirred at r.t. for three days (full conversion of $\mathbf{4 3}$ detected by LC-MS, $254 \mathrm{~nm}$ ). The solution suspension was cooled in an ice bath and $1 \mathrm{~N} \mathrm{HCl}(60 \mathrm{~mL})$ was added while stirring. The mixture was transferred into a separating funnel, vigorously shaken and the organic phase was separated. The aqueous phase was extracted with DCM $(2 \times 50 \mathrm{~mL})$ and to the combined organic phases was added $1 \mathrm{~N} \mathrm{NaOH}(60 \mathrm{~mL})$. The two-phase mixture stirred vigorously at r.t. for $24 \mathrm{~h}$ (complete saponification detected by LC-MS at $254 \mathrm{~nm})$. The aqueous phase was separated, extracted once with DCM $(50 \mathrm{~mL})$ and cooled in an ice-bath. The $\mathrm{pH}$ was adjusted to $1-2$ by slow addition of conc. $\mathrm{HCl}(5 \mathrm{~mL})$ whereby a colorless suspension formed. The solid was vacuum-filtered and washed several times with cold water ( $5 \mathrm{x}$ $3 \mathrm{~mL}$ ). The colorless solid was dried on the air first, then at $70{ }^{\circ} \mathrm{C}$ in fine vacuum to obtain 19 (2.49 g, 8.46 mmol, 72\%). Method 2: A solution of enol ether 17 (0.72 g, $2.94 \mathrm{mmol}, 1.0$ eq.) in dry $\mathrm{MeCN}(25 \mathrm{~mL})$ was prepared in an oven-dried Schlenk flask under nitrogen atmosphere. Amine 16 (0.5 g, $2.94 \mathrm{mmol}, 1.0$ eq.) was added in a single portion and the yellow-greenish solution was heated to reflux for $16 \mathrm{~h}$ (full conversion of 17 detected by LC-MS, 254/315 nm). The orange solution was cooled to r.t. before anhydrous $\mathrm{MgCl}_{2}(0.35 \mathrm{~g}, 3.67 \mathrm{mmol}, 1.25$ eq. $)$ was added. The suspension stirred for $10 \mathrm{~min}$ at r.t. before dry pyridine $(0.71 \mathrm{~mL}, 8.81 \mathrm{mmol}, 3.0$ eq. $)$ was added. The mixture was heated to reflux under nitrogen atmosphere for $24 \mathrm{~h}(95 \%$ conversion 
of 43 detected by LC-MS, $254 \mathrm{~nm}$ ). MeCN was removed in vacuo at $40{ }^{\circ} \mathrm{C}$ and to the brownish salty residue was added DCM $(15 \mathrm{~mL})$. The suspension was cooled in an ice bath and $1 \mathrm{~N} \mathrm{HCl}$ $(15 \mathrm{~mL})$ was added while stirring vigorously. The mixture was transferred into a separating funnel and shaken vigorously. The organic phase was separated and the aqueous phase was extracted with $\operatorname{DCM}(2 \times 10 \mathrm{~mL}) \cdot 1 \mathrm{~N} \mathrm{NaOH}(15 \mathrm{~mL})$ was added to the combined organic phases and the mixture was stirred vigorously at r.t. for $24 \mathrm{~h}$ (complete saponification detected by LC-MS at $254 \mathrm{~nm}$ ). The aqueous phase was separated and extracted once with DCM $(10 \mathrm{~mL})$. The aqueous phase phase was cooled in an ice-bath and conc. $\mathrm{HCl}$ was slowly added for acidification to $\mathrm{pH}=1-2$. A colorless solid precipitated out which was vacuum-filtered and washed with water $(4 \times 2 \mathrm{~mL})$. The solid was dried on the air first, then at $70{ }^{\circ} \mathrm{C}$ under high vacuum to obtain $19(0.46 \mathrm{~g}, 1.56 \mathrm{mmol}$, 53\%). $\boldsymbol{M}\left(\mathrm{C}_{13} \mathrm{H}_{14} \mathrm{~N}_{2} \mathrm{O}_{6}\right): 294.26 \mathrm{~g} / \mathrm{mol} . \boldsymbol{T}_{\mathbf{m}}=248-252{ }^{\circ} \mathrm{C}$ (decomposition). $[\boldsymbol{\alpha}]_{589}^{21}=-120.9$ $(\mathrm{MeCN}, \mathrm{c}=10 \mathrm{mg} / \mathrm{mL}) . \mathbf{R}_{\mathbf{f}}\left(\mathbf{C}_{\mathbf{1 8}}-\mathbf{S i O}_{\mathbf{2}}\right): 0.65\left(\mathrm{EtOH}: \mathrm{H}_{2} \mathrm{O}=2: 1,+20 \%\right.$ HOAc). IR (ATR): $v=$ 1735, 1646, 1618, 1546, 1461, 1440, 1346, 1285, 1095, $1081 \mathrm{~cm}^{-1} .{ }^{1}$ H-NMR, COSY (400 MHz, DMSO-d $\left.{ }_{6}\right): \delta=15.39\left(\mathrm{~s}_{\mathrm{B}}, 1 \mathrm{H},-\mathrm{COOH}\right), 12.77\left(\mathrm{~s}_{\mathrm{B}}, 1 \mathrm{H},-\mathrm{OH}\right), 8.67(\mathrm{~s}, 1 \mathrm{H}, \mathrm{H}-10), 5.52-5.47(\mathrm{~m}$, 1H, H-12a), 4.84-4.75 (m, 1H, H-4), 4.65 (dd, $\left.{ }^{2} J=13.9 \mathrm{~Hz},{ }^{3} J=4.6 \mathrm{~Hz}, 1 \mathrm{H}, \mathrm{H}_{\mathrm{a}}-12\right), 4.43$ (dd, ${ }^{2} J$ $\left.=13.9 \mathrm{~Hz},{ }^{3} J=5.9 \mathrm{~Hz}, 1 \mathrm{H}, \mathrm{H}_{\mathrm{b}}-12\right), 4.09-3.99\left(\mathrm{~m}, 1 \mathrm{H}, \mathrm{H}_{\mathrm{a}}-2\right), 3.95-3.87\left(\mathrm{~m}, 1 \mathrm{H}, \mathrm{H}_{\mathrm{b}}-2\right), 2.09-1.97$ (m, 1H, $\left.\mathrm{H}_{\mathrm{a}}-3\right), 1.60-1.53\left(\mathrm{~m}, 1 \mathrm{H}, \mathrm{H}_{\mathrm{b}}-3\right), 1.34\left(\mathrm{t},{ }^{3} J=7.0 \mathrm{~Hz}, 3 \mathrm{H},-\mathrm{CH}_{3}\right)$ ppm. ${ }^{13} \mathbf{C}-\mathbf{N M R}, \mathbf{H M B C}$, HSQC (101 MHz, DMSO-d 6 ): $\delta=172.2$ (C-8), 165.4 (-COOH), 161.8 (C-6), 153.6 (C-7), 141.1 (C-10), 118.7 (C-6a), 113.0 (C-9), 76.0 (C-12a), 62.0 (C-2), 51.5 (C-12), 44.9 (C-4), 29.1 (C-3), 15.2 $\left(-\mathrm{CH}_{3}\right)$ ppm. ESI-HRMS: calcd for $[\mathrm{M}+\mathrm{H}]^{+}: \mathrm{m} / z=294.0925$, found: $m / z=295.0929$

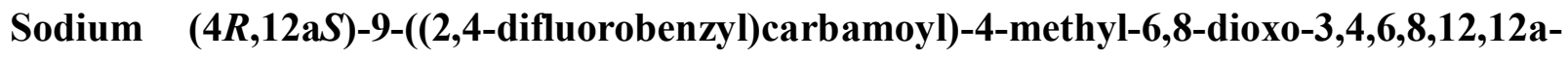
hexahydro-2H-pyrido[1',2':4,5]pyrazino[2,1-b][1,3]oxazin-7-olate (dolutegravir sodium), 15. Method 1: An oven-dried Schlenk flask was charged with ester $18(94 \%, 1.00 \mathrm{~g}, 2.92 \mathrm{mmol}$, 
1.0 eq.), dry toluene $(30 \mathrm{~mL})$, acetic acid $(0.42 \mathrm{~mL}, \quad 7.29 \mathrm{mmol}, \quad 2.5$ eq. $)$ and $2,4-$ difluorobenzylamine (10, $0.87 \mathrm{~mL}, 7.29 \mathrm{mmol}, 2.5$ eq.) under nitrogen atmosphere. The mixture was heated to reflux for $22 \mathrm{~h}$ (full conversion of $\mathbf{1 8}$ detected by LC-MS at 254/315 nm). All volatiles were removed in vacuo at $40^{\circ} \mathrm{C}$ and the residue was dissolved in $\mathrm{EtOH}(30 \mathrm{~mL})$ by heating to reflux. $\mathrm{NaOH}(0.13 \mathrm{~g}, 3.21 \mathrm{mmol}, 1.1$ eq. $)$ was added and the solution was heated again to reflux for two minutes during a beige suspension formed. The mixture was stirred to r.t., filtered and washed with EtOH (4 x $2 \mathrm{~mL})$. The yellow filter cake was dried on the air overnight and transferred into a new flask. EtOH $(15 \mathrm{~mL})$ was added and the suspension was heated again to reflux, hot-filtered hot and washed with hot ethanol $(4 \times 2 \mathrm{~mL})$. The solid was dried on the air overnight, then two hours at $70{ }^{\circ} \mathrm{C}$ in fine vacuum to obtain 15 as faint yellow solid $(0.90 \mathrm{~g}$, 2.04 mmol, 70\%, purity: 99.7\% (254 nm)). Methode 2: An oven-dried flask was charged with acid 19 (1.00 g, 3.40 mmol, 1.0 eq.), carbonyl diimidazole (97\%, 1.14 g, 6.80 mmol, 2.0 eq.) and dry dimethyl carbonate $(30 \mathrm{~mL})$ under nitrogen atmosphere. The suspension was heated to $80{ }^{\circ} \mathrm{C}$ for two hours during a nearly clear orange solution formed. After cooling to r.t., 2,4difluorobenzylamine (10, $0.81 \mathrm{~mL}, 6.80 \mathrm{mmol}, 2.0$ eq.) was added dropwise within two minutes and the solution was stirred for two hours at r.t. (full conversion of 19 detected by LC-MS at 254/315 nm). The solvent was removed in vacuo at $40{ }^{\circ} \mathrm{C}$ and the residue was redissolved in DCM $(30 \mathrm{~mL})$ and $1 \mathrm{~N} \mathrm{NaOH}(30 \mathrm{~mL})$. After stirring for $18 \mathrm{~h}$ at r.t., the colorless suspension was transferred into a separatory funnel. The organic phase was separated and the aqueous phase was extracted twice with DCM $(30 \mathrm{~mL})$. The aqueous phase was cooled in an ice bath, acidified $(\mathrm{pH}=$ 1-2) with conc. $\mathrm{HCl}$ and extracted with $\mathrm{DCM}(3 \times 25 \mathrm{~mL})$. Th combined organic phases were dried over $\mathrm{Na}_{2} \mathrm{SO}_{4}$ and all volatiles were removed in vacuo at $40{ }^{\circ} \mathrm{C}$. The colorless foamy residue was dissolved by heating in $\mathrm{EtOH}(30 \mathrm{~mL})$. $\mathrm{NaOH}(0.15 \mathrm{~g}, 3.74 \mathrm{mmol}, 1.1 \mathrm{eq}$. $)$ was added to the 
hot solution and heating to reflux was continued for two minutes. The suspension was stirred to r.t., filtered and washed with $\mathrm{EtOH}(5 \times 3 \mathrm{~mL})$. The solid was dried on the air overnight, then two hours at $70{ }^{\circ} \mathrm{C}$ under high vacuum to obtain $\mathbf{1 5}$ as a faint yellow solid $(1.41 \mathrm{~g}, 3.19 \mathrm{mmol}, 94 \%$, purity: $99.9 \%(254 \mathrm{~nm})) . \boldsymbol{M}\left(\mathrm{C}_{20} \mathrm{H}_{18} \mathrm{~F}_{2} \mathrm{~N}_{3} \mathrm{NaO}_{5}\right): 441.37 \mathrm{~g} / \mathrm{mol} . \boldsymbol{T}_{\mathbf{m}}=314{ }^{\circ} \mathrm{C}$ (decomposition), Lit.: $296^{\circ} \mathrm{C}^{20} \cdot[\boldsymbol{\alpha}]_{589}^{21}=-46.4\left(\right.$ DMSO-d $\left._{6}, \mathrm{c}=10 \mathrm{mg} / \mathrm{mL}\right) . \mathbf{I R}($ ATR): $v=2975,2913,1641,1537$, 1504, 1424, 1321, 1274, 1258, 1106, $1093 \mathrm{~cm}^{-1} .{ }^{1}$ H-NMR, COSY (400 MHz, DMSO-d 6 ): $\delta=$ $10.69\left(\mathrm{t},{ }^{3} J=6.0 \mathrm{~Hz}, 1 \mathrm{H},-\mathrm{NH}-\right), 7.89$ (s, 1H, H-10), 7.39-7.27 (m, 1H, Ar-H-6), 7.25-7.14 (m, 1H, Ar-H-3), 7.06-6.93 (m, 1H, Ar-H-5), 5.22-5.10 (m, 1H, H-12a), 4.87-4.72 (m, 1H, H-4), 4.50 (d, $\left.{ }^{3} J=6.0 \mathrm{~Hz}, 2 \mathrm{H},-\mathrm{NHCH}_{2} \mathrm{Ar}\right), 4.36-4.24\left(\mathrm{~m}, 1 \mathrm{H}, \mathrm{H}_{\mathrm{a}}-11\right), 4.21-4.08$ (m, 1H, $\left.\mathrm{H}_{\mathrm{b}}-11\right), 4.04-3.87$ (m,

$\left.1 \mathrm{H}, \mathrm{H}_{\mathrm{a}}-2\right), 3.86-3.73\left(\mathrm{~m}, 1 \mathrm{H}, \mathrm{H}_{\mathrm{b}}-2\right), 1.96-1.76\left(\mathrm{~m}, 1 \mathrm{H}, \mathrm{H}_{\mathrm{a}}-3\right), 1.45-1.29\left(\mathrm{~m}, 1 \mathrm{H}, \mathrm{H}_{\mathrm{b}}-3\right), 1.23\left(\mathrm{t},{ }^{3} J\right.$ $\left.=7.0 \mathrm{~Hz}, 3 \mathrm{H},-\mathrm{CH}_{3}\right) \mathrm{ppm} .{ }^{13} \mathbf{C}-\mathbf{N M R}, \mathbf{H M B C}, \mathbf{H S Q C}\left(101 \mathrm{MHz}, \mathrm{DMSO}-\mathrm{d}_{6}\right): \delta=177.9(\mathrm{C}-8)$, 167.0 (C-7), 166.0 (-CONH-), 162.0 (dd, $\left.{ }^{1} J=247 \mathrm{~Hz},{ }^{3} J=12.3 \mathrm{~Hz}, \mathrm{Ar}-\mathrm{C} 2\right), 161.2$ (C-6), 158.8 (dd, $\left.{ }^{1} J=249 \mathrm{~Hz},{ }^{3} J=12.3 \mathrm{~Hz}, \mathrm{Ar}-\mathrm{C} 4\right), 134.4(\mathrm{C}-10), 130.5$ (dd, $\left.{ }^{3} J=9.2 \mathrm{~Hz},{ }^{3} J=6.2 \mathrm{~Hz}, \mathrm{Ar}-\mathrm{C} 6\right)$, 115.0 (C-9), $111.3\left(\mathrm{dd},{ }^{2} J=20.9 \mathrm{~Hz},{ }^{4} J=3.6 \mathrm{~Hz}, \mathrm{Ar}-\mathrm{C} 5\right), 108.9$ (C-6a), 103.7 (t, ${ }^{2} J=25.7 \mathrm{~Hz}, \mathrm{Ar}-$ C3), 75.6 (C-12a), 62.0 (C-2), 53.1 (C-11), 43.1 (C-4), $35.4\left({ }^{3} \mathrm{~J}=3.7 \mathrm{~Hz},-\mathrm{NHCH}_{2} \mathrm{Ar}\right), 29.2$ (C-3), $15.3\left(-\mathrm{CH}_{3}\right)$ ppm. ESI-MS: $\left.m / z=418.2(100 \% \text {, [M-Na }]^{-}\right)$. The spectroscopic data are consistent with literature values. ${ }^{?}$

\section{Associated content}

Supporting Information

Optimization studies, chromatograms, VCD spectroscopy, computational details and NMRspectra (PDF).

\section{AUTHOR INFORMATION}


Corresponding Author

Till Opatz - Department of Chemistry, Johannes Gutenberg-University, Duesbergweg 10-14, 55128 Mainz, Germany, Email: opatz@uni-mainz.de

\section{Funding}

This work was supported by the Bill and Melinda Gates Foundation.

\section{Notes}

The authors declare no competing financial interest.

\section{ACKNOWLEDGMENT}

This work was supported by the Bill and Melinda Gates Foundation through the Medicines for All initiative. We thank Dr J. C. Liermann (Mainz) for NMR spectroscopy and Dr C. J. Kampf(Mainz) for mass spectrometry. Parts of this research were conducted using the supercomputer MOGON and/or advisory services offered by Johannes Gutenberg University Mainz (hpc.uni-mainz.de), which is a member of the AHRP (Alliance for High Performance Computing in Rhineland Palatinate, www.ahrp.info) and the Gauss Alliance e.V. The authors gratefully acknowledge the computing time granted on the supercomputer Mogon at Johannes Gutenberg University Mainz (hpc.uni-mainz.de).

\section{References}

(1) https://www.avert.org/global-hiv-and-aids-statistics (accessed March 29, 2021).

(2) Cihlar, T.; Fordyce, M. Current status and prospects of HIV treatment. Current opinion in virology 2016, $18,50-56$.

(3) https://www.fda.gov/news-events/press-announcements/fda-approves-first-extended-releaseinjectable-drug-regimen-adults-living-hiv (accessed March 21, 2021).

(4) Hughes, D. L. Review of Synthetic Routes and Final Forms of Integrase Inhibitors Dolutegravir, Cabotegravir, and Bictegravir. Org. Process Res. Dev. 2019, 23, 716-729. 
(5) https://www.who.int/hiv/pub/arv/arv-update-2019-policy/en/ (accessed March 21, 2021).

(6) Synthesis of heterocycles in contemporary medicinal chemistry; Časar, Z.; Barth, R., Eds.; Topics in heterocyclic chemistry 44; Springer: Switzerland, 2016.

(7) Sankareswaran, S.; Mannam, M.; Chakka, V.; Mandapati, S. R.; Kumar, P. Identification and Control of Critical Process Impurities: An Improved Process for the Preparation of Dolutegravir Sodium. Org. Process Res. Dev. 2016, 20, 1461-1468.

(8) https://medicines4all.vcu.edu/our-portfolio/bmgf-projects/r-3-aminobutanol-batch-/ (accessed March 12, 2021).

(9) Lerner, C.; Krei, L.; Hilpert, H. Pyrimidone derivatives and their use in treatment, amelioration or prevention of a viral disease. Patent WO158151A1, 2017.

(10) Jee, J.; Gade, N.; Roper, T. Novel pyrrole and pyridone derivatives and uses thereof. Patent WO081143A1, 2020.

(11) Luu, Q. H.; Guerra, J. D.; Castañeda, C. M.; Martinez, M. A.; Saunders, J.; Garcia, B. A.; Gonzales, B. V.; Aidunuthula, A. R.; Mito, S. Ultrasound assisted one-pot synthesis of benzo-fused indole-4,9dinones from 1,4-naphthoquinone and $\alpha$-aminoacetals. Tetrahedron Letters 2016, 57, 2253-2256.

(12) Jones, R. G. The Synthesis of Ethyl Ethoxymethyleneoxalacetate and Related Compounds. J. Am. Chem. Soc. 1951, 73, 3684-3686.

(13) Ziegler, R. E.; Desai, B. K.; Jee, J.-A.; Gupton, B. F.; Roper, T. D.; Jamison, T. F. 7-Step Flow Synthesis of the HIV Integrase Inhibitor Dolutegravir. Angewandte Chemie (International ed. in English) 2018, 57, 7181-7185.

(14) Sumino, Y.; Okamoto, K.; Masui, M.; Yamada, D.; Ikarashi, F. Process for preparing compund having HIV integrase activity. Patent EP2602260A1.

(15) Phull, M.; Rao, D.; Birari, D. A process for the preparation of bictegravir and intermediate thereof. Patent WO229798A1, 2018.

(16) Budidet, S.; Dussa, N.; Kaki, G.; Yatcherla, S.; Sanapureddy, J.; Danda, S.; Katuroju, S.; Meenakshisunderam, S. An improved proecess for the preparation of dolutegravir. Patent WO128545A2, 2014.

(17) Juhász, M.; Lázár, L.; Fülöp, F. Substituent effects in the ring-chain tautomerism of 4-alkyl-2-aryl substituted oxazolidines and tetrahydro-1,3-oxazines. Journal of Heterocyclic Chemistry 2007, 44, 14651473. 
(18) Gu, N.; Liu, M.; Wang, H.; Sun, S.; Zhou, Z.; Hu, W.; Yu, J.-T.; Cheng, J. Iridium-catalyzed annulation between 1,2-diarylethanone and 3-aminopropanol toward site-specific 2,3-diaryl pyridines. Tetrahedron Letters 2017, 58, 3398-3400.

(19) Kaye, I. A.; Minsky, I. New Compounds. Preparation of N-Substituted Aminoacetals. J. Am. Chem. Soc. 1949, 71, 2272-2273.

(20) Hotter, A.; Thaler, A.; Lebar, A.; Jankovic, B.; Naversnik, K.; Klancar, U.; Abramovic, Z. Novel Hydrates of Dolutegravir Sodium. Patent WO2016016279A1. 